\title{
Projected future changes in rainfall in Southeast Asia based on CORDEX-SEA multi-model simulations
}

\author{
Fredolin Tangang ${ }^{1,2}$ (D) Jing Xiang Chung ${ }^{1,3} \cdot$ Liew Juneng $^{1} \cdot$ Supari $^{1,4} \cdot$ Ester Salimun $^{1} \cdot$ Sheau Tieh Ngai ${ }^{1}$. \\ Ahmad Fairudz Jamaluddin ${ }^{1,5}$. Mohd Syazwan Faisal Mohd ${ }^{6} \cdot$ Faye Cruz $^{7}$. Gemma Narisma ${ }^{7,8}$. \\ Jerasorn Santisirisomboon ${ }^{2}$. Thanh Ngo-Duc ${ }^{9}$. Phan Van $\operatorname{Tan}^{10}$. Patama Singhruck ${ }^{11}$. Dodo Gunawan ${ }^{4}$. \\ Edvin Aldrian ${ }^{12}$ - Ardhasena Sopaheluwakan $^{13} \cdot$ Nikulin Grigory $^{14}$ - Armelle Reca C. Remedio ${ }^{15}$. Dmitry V. Sein ${ }^{16,17}$. \\ David Hein-Griggs ${ }^{18,19}$. John L. McGregor ${ }^{20} \cdot$ Hongwei Yang $^{21,22} \cdot$ Hidetaka Sasaki $^{23} \cdot$ Pankaj Kumar $^{24}$
}

Received: 8 October 2019 / Accepted: 30 May 2020 / Published online: 9 June 2020

(c) The Author(s) 2020

\begin{abstract}
This paper examines the projected changes in rainfall in Southeast Asia (SEA) in the twenty-first century based on the multimodel simulations of the Southeast Asia Regional Climate Downscaling/Coordinated Regional Climate Downscaling Experiment-Southeast Asia (SEACLID/CORDEX-SEA). A total of 11 General Circulation Models (GCMs) have been downscaled using 7 Regional Climate Models (RCMs) to a resolution of $25 \mathrm{~km} \times 25 \mathrm{~km}$ over the SEA domain $\left(89.5^{\circ} \mathrm{E}-146.5^{\circ} \mathrm{E}, 14.8^{\circ}\right.$ $\mathrm{S}-27.0^{\circ} \mathrm{N}$ ) for two different representative concentration pathways (RCP) scenarios, RCP4.5 and RCP8.5. The 1976-2005 period is considered as the historical period for evaluating the changes in seasonal precipitation of December-January-February (DJF) and June-July-August (JJA) over future periods of the early (2011-2040), mid (2041-2070) and late twenty-first century (2071-2099). The ensemble mean shows a good reproduction of the SEA climatological mean spatial precipitation pattern with systematic wet biases, which originated largely from simulations using the RegCM4 model. Increases in mean rainfall (10-20\%) are projected throughout the twenty-first century over Indochina and eastern Philippines during DJF while a drying tendency prevails over the Maritime Continent. For JJA, projections of both RCPs indicate reductions in mean rainfall (10-30\%) over the Maritime Continent, particularly over the Indonesian region by mid and late twenty-first century. However, examination of individual member responses shows prominent inter-model variations, reflecting uncertainty in the projections.
\end{abstract}

Keywords Projected rainfall $\cdot$ Regional climate downscaling $\cdot$ Multi-model simulations $\cdot$ CORDEX Southeast Asia

\section{Introduction}

The Southeast Asia (SEA) region, which comprises least developed and developing countries, has been frequently impacted by climate-related disasters such as floods and droughts (Hijioka et al. 2014). With high exposure and low resilience, the SEA region is vulnerable to climate change impacts as the intensity and frequency of extreme events may increase in the future (Ge et al. 2019; Kang et al.

Electronic supplementary material The online version of this article (https://doi.org/10.1007/s00382-020-05322-2) contains supplementary material, which is available to authorized users.

Fredolin Tangang

tangang@ukm.edu.my

Extended author information available on the last page of the article
2019; Manomaiphiboon et al. 2013; Ngo-Duc et al. 2014; Raghavan et al. 2017). In particular, a major shift in seasonal rainfall patterns, as well as increases in occurrences of floods and drought would have huge implications on livelihoods, infrastructures, agricultural outputs and food security. For countries to mitigate and adapt to the impacts of future climate change and to increase resilience, policymakers and practitioners must have access to robust information on how future climate change will affect critical sectors in their countries. However, the Working Group II of the Intergovernmental Panel on Climate Change (IPCC) Fifth Assessment Report indicated significant knowledge gap on impacts of future climate change on critical sectors in SEA (Hijioka et al. 2014), which could partly be attributed to the unavailability of high-resolution multi-model climate simulations in the region. 
While future climate projections at global scales have existed from the large collection of simulations using general circulation models (GCMs) under the Coupled Model Intercomparison Projects (CMIPs) (Meehl et al. 2000), the coarse resolution of GCMs (typically at 100-300 km) rendered their applications in climate change impact assessments at local scales less practical (Giorgi et al. 2009; Giorgi and Mearns 1991). Regional climate downscaling, either statistically or dynamically, offers a solution in which information at the local and regional scales can be generated from coarse GCM outputs (Christensen et al. 2007; Fowler et al. 2007; Giorgi et al. 2009; Giorgi and Mearns 1991; Hewitson and Crane 1996; McGregor 1997; McGregor et al. 1993; Wilby and Wigley 1997). While statistical downscaling (SD) does not require large computing resources, its application is dependent on the availability of long time-series of reliable and good quality observed data (Murphy 1999; Tang et al. 2016). Since there is limited access to observed data with sufficiently long temporal coverage and good quality in SEA, the application of SD in this region can be less practical. Furthermore, in the SD approach, the dynamics and climate feedbacks at small scales are not taken into account, and statistical relationships between large and small scales in the future might be different from those in the past and present. On the other hand, dynamically downscaling (DD) can be difficult and time-consuming to implement because of the huge computing resources required to have multiple GCMs, regional climate models (RCMs) and greenhouse gas (GHG) concentration scenarios to generate a range of plausible regional climate change projections (Giorgi et al. 2009; Giorgi and Mearns 1991; Valle et al. 2009).

Modulated by the Asian-Australian monsoon system, the climate of SEA is considered very complex. It is largely characterized by the asymmetric seasonal march of maximum convection from the northern parts of the region during the summer monsoon to the southern parts of SEA during the winter monsoon (Chang et al. 2005; Robertson et al. 2011; Waliser and Gautier 1993). Hence, the maximum rainfall in Indochina occurs during boreal summer while most areas in the Maritime Continent experience maximum rainfall during boreal winter (Chang et al. 2005; Waliser and Gautier 1993). However, with complex terrains where many islands of different sizes are interspersed among regional seas, the regional and local climates of SEA are considered unique in its spatial and temporal variability. In addition, the SEA climate also shows intraseasonal to interannual variations concurrent with the El Niño-Southern Oscillation (ENSO) (e.g. Wang et al. 2003; Tangang and Juneng 2004; Juneng and Tangang 2005, Phan et al. 2009; Salimun et al. 2014; Villafuerte and Matsumoto 2015; Tangang et al. 2017; Limsakul et al. 2017; Supari et al. 2018) and Madden-Julian Oscillation (e.g. Tangang et al. 2008; Hidayat and Kizu 2010; van der Linden et al. 2016; Birch et al. 2016; Kim et al. 2017; Xavier et al. 2020). Hence, simulating the past and projecting future climate over the region can be challenging.

In contrast to developed regions such as Europe and North America, the number of regional climate simulations carried out in SEA, which can be reliably used for impact assessments, is limited. Most studies have been limited by the use of a single GCM and RCM, except a few recent ones where multiple GCMs have been downscaled using a single RCM, focusing on some parts of SEA. For example, Kang et al. (2019) used a single RCM to downscale three GCMs over a model domain that covered the Maritime Continent but excluded mainland Southeast Asia. On the other hand, in Rahmat et al. (2014), ECHAM5 and several perturbed Hadley Centre GCMs have been dynamically downscaled over the SEA region. Some countries in SEA have also carried out future climate projection studies, e.g. Vietnam (Katzfey et al. 2014; Ngo-Duc et al. 2014), Philippines (Villafuerete et al. 2019), Malaysia (NAHRIM 2006), and Indonesia (McGregor et al., 2016).

On a more encouraging note for SEA was the recent completion of high-resolution multi-model regional climate simulations of the Southeast Asia Regional Climate Downscaling/Coordinated Regional Climate Downscaling Experiment-Southeast Asia (SEACLID/CORDEX-SEA, hereafter referred to as CORDEX-SEA) (Tangang et al. 2018, 2019). Launched in November 2013, the CORDEX-SEA project was carried out by a consortium of many institutions from within and outside the region, and represents the most comprehensive set of simulations over SEA thus far (https://www.ukm.edu.my/seaclid-cordex). Based on these simulations, several papers have already been published recently. Tangang et al. (2019) and TrinhTuan et al. (2019) used a subset of the CORDEX-SEA simulations for assessment over Thailand and Vietnam, respectively. Herrmann et al. (2020) used one model member of the CORDEX-SEA simulations in investigating the projected changes of sea surface wind in the region. Ge et al. (2019) used three members of the CORDEX-SEA simulations in analysing extreme precipitation over SEA related to 1.5 and $2.0^{\circ} \mathrm{C}$ warming. Tangang et al. (2018) also investigated extreme precipitation over SEA under global warming of $2{ }^{\circ} \mathrm{C}$ based on a subset of the CORDEX-SEA simulations. A recent study by Supari et al. (2020) evaluated changes in extreme precipitation over SEA region in the twenty-first century. Using available members of the CORDEX-SEA simulations, the present study aims to analyse the performance of models in simulating December-January-February (DJF) and June-July-August (JJA) mean rainfall in the historical period and evaluate future changes. This paper should serve as a standard reference for CORDEX simulations over the SEA region. 


\section{Models, simulation setups and observed data}

Table 1 provides a list of the simulations conducted in CORDEX-SEA with 7 RCMs and 11 driving CMIP Phase 5 (CMIP5) GCMs and considered as an "ensemble of opportunity" (Daron et al. 2018). A description of the RCMs used is provided in Table 2. Most of the GCMs have been evaluated on their ability to reproduce the monsoonal circulations and climatology over this region in previous studies (Katzfey et al. 2016; McGregor et al. 2016; McSweeney et al. 2015; Nguyen and McGregor 2009; Siew et al. 2014). Figure 1 shows the CORDEX-SEA simulation domain of $89.5^{\circ} \mathrm{E}$ to $146.5^{\circ} \mathrm{E}$ and $14.8^{\circ} \mathrm{S}$ to $27.0^{\circ} \mathrm{N}$, covering the SEA region with $25 \mathrm{~km} \times 25 \mathrm{~km}$ horizontal resolution. Note that the simulation using MPI-ESM-LR/ROM was on $50 \mathrm{~km} \times 50 \mathrm{~km}$ resolution with a bigger domain that extended eastward to cover the warm pool of western Pacific Ocean (Sein et al. 2015). The periods of simulations vary from model to model, but most runs cover the period from the 1970s to 2099 and use both scenarios of RCP4.5 and RCP8.5. However, in some simulations, including HadGEM2-ES/PRECIS, ACCESS1.0/CCAM, CCSM4/CCAM and CNRM-CM5/ CCAM, the runs were only available for RCP8.5. The CCAM and NHRCM simulations were available as timeslice runs, wherein the MRI-AGCM/NHRCM runs covered the 1981-2000 and 2080-2099 periods. In this study, the 1976-2005 period is considered as historical period, while 2011-2040, 2041-2070, and 2071-2099 as early, mid, and late twenty-first century projection periods, respectively.

The seven RCMs used in this study utilized various parameterization schemes (Table 2). For RegCM4, WRF and RCA4, brief descriptions of parameterization schemes employed, model configuration and setup were provided in Tangang et al. (2019). The details of the ROM implementation can be found in Sein et al. (2015), while the NHRCM details are given in Cruz and Sasaki (2017). Within the PRECIS regional climate modelling system (Jones et al. 2004), the HadRM3P RCM (Massey et al. 2015) is a hydrostatic, 19 hybrid sigma level model, which utilises a rotated north pole coordinate system at $25 \mathrm{~km} \times 25 \mathrm{~km}$ horizontal resolution. HadRM3P dynamically downscales HadGEM2-ES by gradually relaxing data saved at six hourly instantaneous frequency for surface pressure as well as three-dimensional horizontal winds, moisture and temperature. HadRM3P is forced with surface boundary conditions (skin temperature and sea ice fraction) from the driving HadGEM2-ES as well as atmospheric boundary conditions for ozone concentration, sulphur dioxide and dimethyl sulphide and volcanic aerosol.

Simulations using CCAM, a stretched-grid GCM, were performed in two stages. First, three quasi-uniform simulations with $100 \mathrm{~km}$ resolution are performed from 1971 to 2071 driven by the sea-ice and bias-corrected monthly

Table 1 The list of simulations carried out in CORDEX-SEA

\begin{tabular}{|c|c|c|c|c|c|}
\hline \multirow{2}{*}{$\begin{array}{l}\text { Ensemble } \\
\text { member }\end{array}$} & \multirow[t]{2}{*}{ GCM } & \multirow[t]{2}{*}{$\mathrm{RCM}$} & \multicolumn{3}{|c|}{ Projection Periods of 21st Century } \\
\hline & & & $\begin{array}{l}\text { Early (2011- } \\
\text { 2040) }\end{array}$ & $\begin{array}{l}\text { Mid (2041- } \\
\text { 2070) }\end{array}$ & $\begin{array}{l}\text { End } \\
(2071- \\
2099)\end{array}$ \\
\hline 1 & CNRM-CM5 (CNRM, France) & RegCM4 (ICTP, Italy) & $\mathrm{x}$ & $\mathrm{x}$ & $\mathrm{x}$ \\
\hline 2 & HadGEM2-ES (Hadley Centre, UK) & RegCM4 (ICTP, Italy) & $\mathrm{x}$ & $\mathrm{x}$ & $\mathrm{x}$ \\
\hline 3 & MPI-ESM-MR (MPI-M, Germany) & RegCM4 (ICTP, Italy) & $\mathrm{x}$ & $\mathrm{x}$ & $\mathrm{x}$ \\
\hline 4 & EC-Earth (EC-Earth consortium) & RegCM4 (ICTP, Italy) & $\mathrm{x}$ & $\mathrm{x}$ & $\mathrm{x}$ \\
\hline 5 & CSIRO MK3.6 (CSIRO, Australia) & RegCM4 (ICTP, Italy) & $\mathrm{x}$ & $\mathrm{x}$ & $\mathrm{x}$ \\
\hline 6 & CNRM-CM5 (CNRM, France) & RCA4 (SMHI, Sweden) & $\mathrm{x}$ & $\mathrm{x}$ & $\mathrm{x}$ \\
\hline 7 & MPI-ESM-LR(MPI, Germany) & ROM(GERICS-AWI, Germany) ${ }^{\mathrm{b}}$ & $\mathrm{x}$ & $\mathrm{x}$ & $\mathrm{x}$ \\
\hline 8 & HadGEM2-ES (Hadley Centre, UK) & RCA4 (SMHI, Sweden) & $\mathrm{x}$ & $\mathrm{x}$ & $\mathrm{x}$ \\
\hline 9 & ACCESS1.0 (CSIRO, Australia) & CCAM (CSIRO, Australia) $)^{\mathrm{a}}$ & & $\mathrm{x}$ & \\
\hline 10 & MRI-AGCM (MRI, Japan) & NHRCM (MRI, Japan) ${ }^{\mathrm{c}}$ & & & $\mathrm{x}$ \\
\hline 11 & HadGEM2-AO (Hadley Centre, UK) & WRF (NCAR USA) & $\mathrm{x}$ & $\mathrm{x}$ & $\mathrm{x}$ \\
\hline 12 & HadGEM2-ES (Hadley Centre, UK) & PRECIS (Hadley Centre, UK) ${ }^{\mathrm{a}}$ & $\mathrm{x}$ & $\mathrm{x}$ & $\mathrm{x}$ \\
\hline 13 & CCSM4 (NCAR, USA) & CCAM (CSIRO, Australia) ${ }^{\mathrm{a}}$ & & $\mathrm{x}$ & \\
\hline 14 & CNRM-CM5 (CNRM, France) & CCAM (CSIRO, Australia $)^{\mathrm{a}}$ & & $\mathrm{x}$ & \\
\hline
\end{tabular}

${ }^{\mathrm{a}}$ Only RCP8.5

${ }^{\mathrm{b}} 50 \mathrm{~km} \times 50 \mathrm{~km}$ resolution with larger domain size to cover warm pool of western Pacific Ocean

${ }^{\mathrm{c}}$ Baseline period (1981-2000), end of 21st period (2080-2099) 


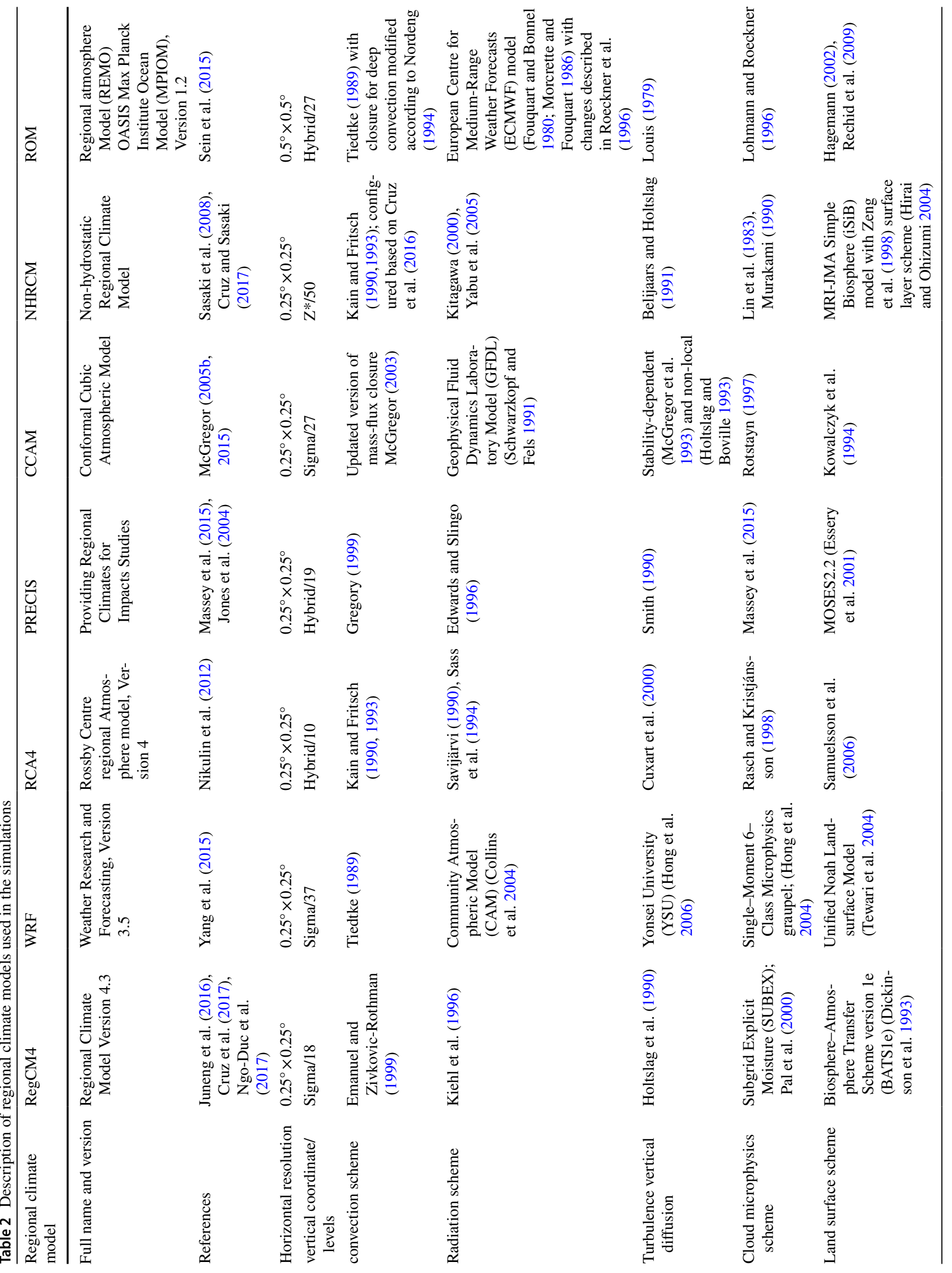


sea surface temperatures (SSTs) from the ACCESS1.0, CCSM4, and CNRM-CM5 simulations of CMIP5 for the RCP8.5 scenario. These $100 \mathrm{~km}$ simulations provide the initial conditions and large-scale atmospheric forcing (Thatcher and McGregor 2009) for the following variableresolution $25 \mathrm{~km}$ simulations: ACCESS1.0 for 1971-2005, ACCESS1.0 for 2041-2072, CCSM4 for 2041-2075 and CNRM-CM5 for 2041-2071. The ACCESS1.0 simulation for 1971-2005 is regarded as the "present-day" $25 \mathrm{~km} \mathrm{sim-}$ ulations for all the runs, as the other GCMs will produce similar climatologies for this period as a result of the biascorrection of their SSTs. The CCAM regional climate simulations used a quasi-uniform C96 conformal-cubic global grid $(6 \times 96 \times 96$ grid points). The $25 \mathrm{~km}$ simulations used a C120 grid with Schmidt (1977) transformation having a stretching factor of 3.2. Details of the CCAM dynamical formulation and downscaling strategy are provided by McGregor (2005a, 2015). The cumulus convection scheme is an updated version of the mass-flux closure described by McGregor (2003) and includes entrainment, detrainment and downdrafts. A description of the other model parameterizations is provided by McGregor et al. (2016).

In this study, model performances have been evaluated for the historical period (1976-2005) using reanalysis winds from ERA Interim reanalysis $\left(0.25^{\circ} \times 0.25^{\circ}\right.$; Dee et al. 2011) and precipitation from the Global Precipitation Climatology Centre (GPCC) $\left(0.5^{\circ} \times 0.5^{\circ}\right.$ resolution; Schneider et al. 2014). Other gridded precipitation datasets have also been included in the analysis, such as the Asian Precipitation-Highly-Resolved Observational Data Integration Towards Evaluation of water resources (APHRODITE) $\left(0.25^{\circ} \times 0.25^{\circ}\right.$ resolution; Yatagai et al. 2012), the Climatic Research Unit of the University of East Anglia (CRU) TS3.23 $\left(0.25^{\circ} \times 0.25^{\circ}\right.$ resolution; Mitchell and Jones 2005), the Tropical Rainfall Measuring Mission (TRMM) $3 \mathrm{~B} 42$ version $7\left(0.25^{\circ} \times 0.25^{\circ}\right.$ resolution; Huffman et al. 2007) and the Climate Hazards Group Infrared Precipitation with Stations (CHIRPS) $\left(0.25^{\circ} \times 0.25^{\circ}\right.$ resolution; Funk et al. 2015).

The statistical significance of biases and projected changes have been calculated using thresholds based on the Monte Carlo permutation test (Baez and Tweed 2013). The $90 \%$ significance level of biases and projected changes above random noise are indicated in the maps as forward slashes. Furthermore, the model agreement in the sign of change (henceforth referred as robustness) is also determined, wherein the minimum number of models required to agree was determined using a binomial probability function (Vautard et al. 2014). This model agreement in the sign of changes at $75 \%$ level of confidence is indicated in the maps as backslashes. Outputs of driving GCMs are also included in the analysis for comparison with RCM simulations.

\section{Results}

\subsection{Model performances}

\subsubsection{Monsoon circulations}

The atmospheric circulation over Southeast Asia is largely modulated by the Asian-Australian monsoon, in which the migration of the Intertropical Convergence Zone (ITCZ) and monsoon trough influences the rainfall distribution over the region (Chang et al. 2005; Robertson et al. 2011; Waliser and Gautier 1993). Hence, models must be able to simulate this regional circulation to correctly capture the rainfall distribution. In addition, knowledge of future changes in regional circulation is relevant in explaining changes in precipitation. It is thus necessary to evaluate the performance of the models in simulating the monsoonal circulation, which could be represented by the low-level circulation during DJF and JJA for the winter and summer monsoon circulations over Southeast Asia, respectively (Chang et al. 2005).

The RCM ensemble mean $850 \mathrm{hPa}$ winds for DJF and JJA are shown in Fig. 2. Due to the unavailability of wind data from some simulations at the time of analysis, the ensemble consisted only the first nine members in Table 1, excluding HadGEM2-AO(WRF), HadGEM-ES(PRECIS), and MRIAGCM(NHRCM). For comparison, the climatological mean of ERA-Interim and ensemble mean of the forcing GCMs are also shown in Fig. 2, as well as the corresponding biases of RCM and GCM relative to ERA-Interim. Despite notable magnitude of biases, both GCM and RCM ensemble means display some consistency, and capture the general pattern of the low-level circulation of ERA-Interim for both seasons. During DJF, the easterly component of the winds in the RCM tends to be stronger over mainland SEA and the Bay of Bengal compared to that of ERA-Interim. RCM wind speeds are also overestimated over Java and an area north of Papua. Similar biases are evident in the GCM. Relatively large biases can be seen during JJA with stronger simulated monsoonal wind along the latitudinal band of $18^{\circ} \mathrm{N}$ in RCM compared to ERA-Interim. Biases are also notable over the Maritime Continent and western Pacific. Despite the consistency of both RCM and GCM ensemble means to ERA-Interim, inter-model variations within RCMs and GCMs exist (Supplementary Figures Fig. S1 to Fig. S4). The differences in RCMs can largely be traced to the forcing GCMs. However, in some simulations notable modifications can be made by the RCM. For example, in HadGEM2-ES (RegCM4) during DJF, strong southerly winds can be found over eastern Indian Ocean and west of Sumatra in RCM but absent in HadGEM2-ES (Fig. S3 vs. Fig. S4).

In addition to the low-level circulation, it is also useful to evaluate how the models simulate the subsidence field 
Fig. 1 The geographical map of Southeast Asia region and CORDEX-SEA domain. Indicated in the map are the 20 sub-regions, selected for model evaluation

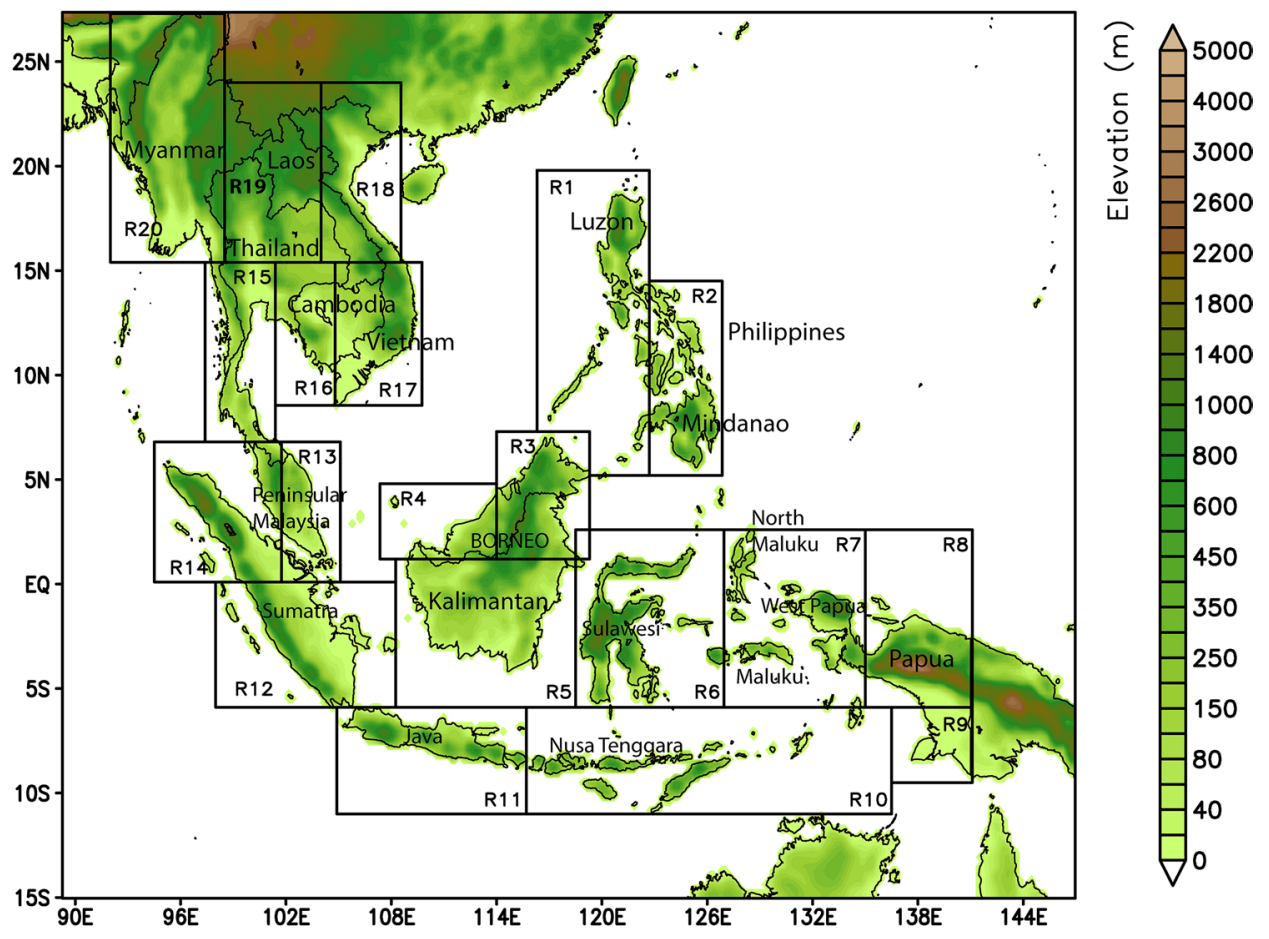

as rainfall and subsidence can be tightly linked (e.g. Luis and Pandey 2003; Chang et al. 2005; Hill et al. 2018). However, since the vertical velocity is not available for some models, the divergence at $850 \mathrm{hPa}$ was used as the divergence (convergence) corresponds to subsidence (rising motion) (e.g. Tangang et al. 2019). Figure 3 shows the ERA-Interim and RCM ensemble mean divergence at $850 \mathrm{hPa}$ for DJF and JJA. The divergence fields of GCM have similar patterns with the RCM (not shown). Despite the existence of inter-model variations among the experiments (not shown), the RCM ensemble mean divergence captured the general patterns of those of ERA-Interim well. In terms of consistency, models tend to show high agreement in the sign of biases over the ocean than over land (Fig. 3).

During DJF, both ERA-Interim and the RCM ensemble mean indicate mostly convergence (rising motion) over the Indonesian region centered at $5^{\circ} \mathrm{S}$, and divergence (subsidence) over the northern part of the domain centered at $18^{\circ}$ $\mathrm{N}$, especially over mainland SEA. The area of convergence over Indonesia corresponds well with the location of the ITCZ during winter monsoon (Waliser and Gautier 1993). Interestingly, despite overall divergent low-level flow in mainland SEA, low-level wind convergence can be seen over the northwest corner of the domain covering the north of Myanmar, Thailand and Laos. Convergence over an area over the southeast of Vietnamese coast can also be found in the ERA-Interim and this is well simulated by the RCM ensemble mean. The RCM ensemble mean also approximates the divergences shown in ERA-Interim during JJA, in which the pattern is roughly opposite to that of DJF. However, some differences at sub-regional/local scales exist. For example, over Peninsular Malaysia, divergence (subsidence) is indicated in ERA-Interim. However, the area is dominated by convergence (rising motion) in the RCM ensemble mean, creating large negative biases in divergence fields.

\subsubsection{Seasonal precipitation}

Figure 4 shows the zonally averaged annual cycle of precipitation of GPCC, and the ensemble means of RCMs and GCMs, averaged over the historical period. The "A" shape of GPCC represents the rainfall temporal-spatial distribution over SEA, which is modulated by the Asian-Australian monsoon cycle. During boreal winter, the ITCZ is located around $3-5^{\circ} \mathrm{S}$ with relatively higher rainfall over these latitudinal bands (Chang et al. 2005; Robertson et al. 2011). Due to the asymmetrical nature of the Asian-Australian monsoon system, the ITCZ is located around $15-20^{\circ} \mathrm{N}$ during boreal summer (Chang et al. 2005). Hence, the "A" shape represents the ITCZ migration between these two latitudinal bands. Despite inter-model variations (not shown), which is largely reflected in rainfall intensity, all RCMs and GCMs generally simulated the observed "A" pattern. However, the rainfall intensity in RCM ensemble appears higher compared to GCM. For the RCM simulations, RegCM4 and WRF simulations tended to have wet biases while RCA4, PRECIS, ROM and NHRCM produced dry biases, relative to GPCC (not shown). 

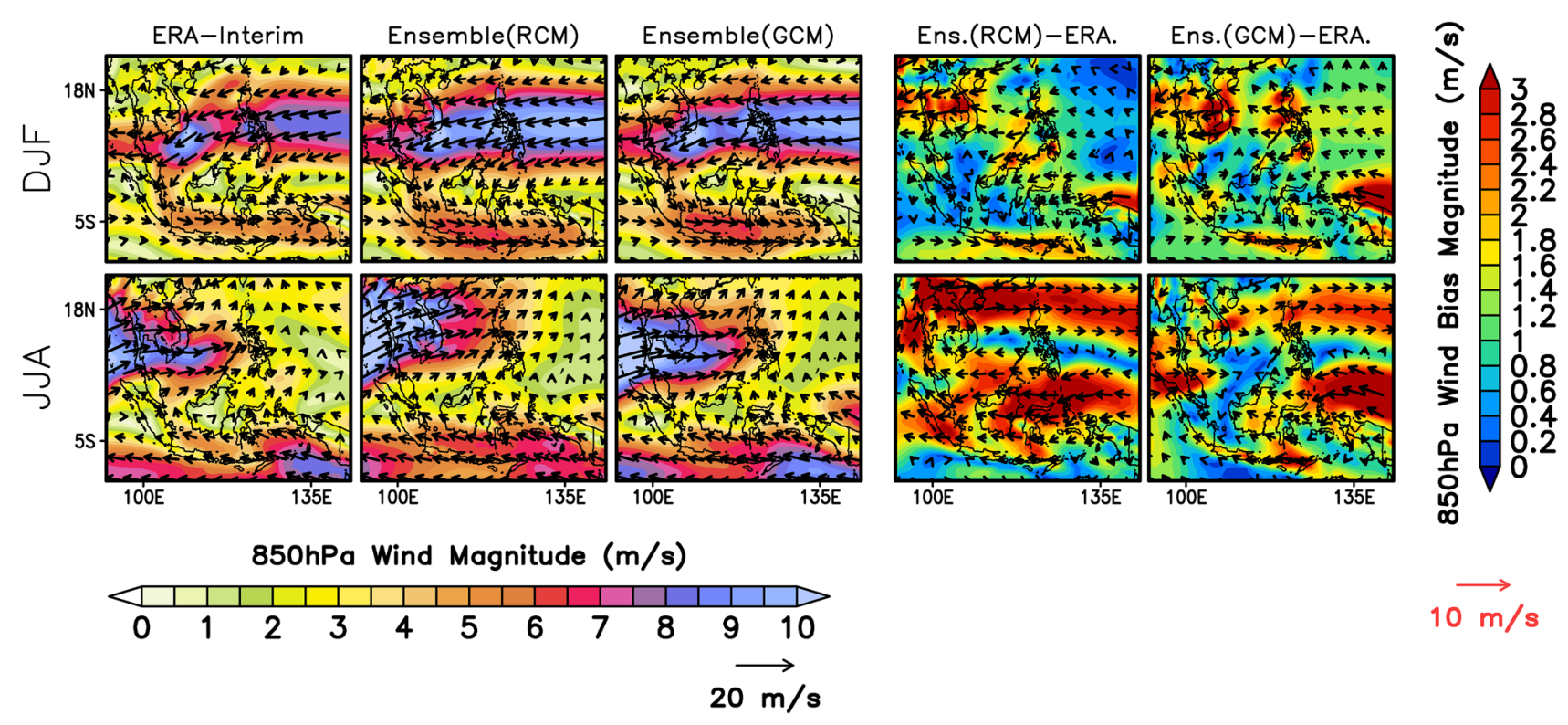

Fig. 2 The comparison between ERA-Interim $850 \mathrm{hPa}$ winds (first column) and RCM ensemble mean (middle column), and GCM ensemble mean (third column) during historical period. The respec-

tive biases are shown in the last two columns. The first (second) row represents DJF (JJA) seasonal mean. The RCM and GCM ensembles mean were averaged from 9 and 8 members, respectively
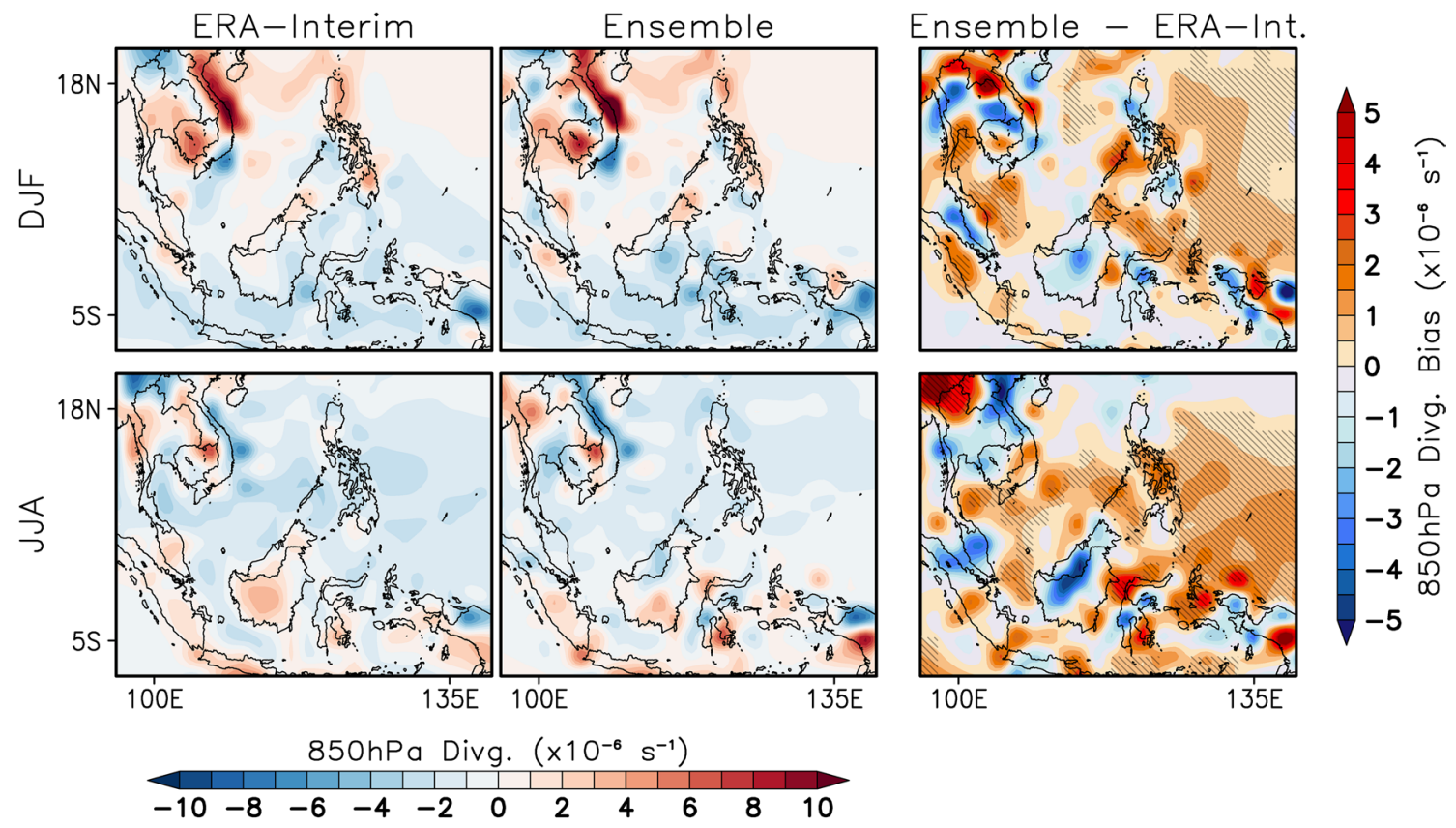

Fig. 3 The seasonal divergence field of ERA-Interim (first column), RCM ensemble mean (second column) and biases (third column). The ensemble mean was based on 9 members. The first (second) row

Figure 5 shows the seasonal climatological rainfall of DJF and JJA of GPCC, the ensemble means of RCMs and GCMs, and their corresponding biases relative to GPCC, averaged over the historical period. Consistent with Fig. 4, the observed spatial distribution of mean rainfall of GPCC represents DJF (JJA) seasonal mean. Backslashes indicate model agreement in the sign of biases at $75 \%$ confidence level

shows the north-south gradient, reflecting the Asian-Australian monsoon modulation (Chang et al. 2005; Robertson et al. 2011; Waliser and Gautier 1993). During DJF low (high) rainfall is depicted over Indochina (Maritime Continent). The high rainfall over the Maritime Continent is 
associated with the monsoonal winds that transport moisture from the South China Sea (Fig. 2) and enhanced convergence (Fig. 3). However, spatial variability can be prominent in some areas in the Maritime Continent, e.g. over Borneo, southern Sumatra and Java (Fig. 5). Over central-western Borneo, high rainfall during DJF is modulated by the existence of the synoptic-scale Borneo vortex (Chen et al. 2013a, b; Tangang et al. 2012). Over Java and southern Sumatra, high rainfall usually occurs in February when the crossequatorial wind strengthens and the ITCZ is located over its southernmost location (e.g. Chang et al. 2005; Tangang et al. 2008). During JJA, rainfall is high over Indochina especially along the coast of Myanmar due to the boreal summer monsoonal winds that transport moisture from the Indian Ocean and Bay of Bengal (Chang et al. 2005). Due to the topographic effect, high rainfall can also be seen in the mountainous region over Laos, and north and central regions of Vietnam.

Despite the complexity in the spatial distribution of seasonal rainfall, both the RCM and GCM ensemble means appear to well reproduce the main feature, i.e., the north-south gradient in the rainfall pattern and intensity. However, unlike the RCM, the GCM was unable to simulate the fine details of the rainfall distribution. Features of high rainfall over central-western Borneo, Java and southern Sumatra during DJF, and over Laos and northern Vietnam during JJA, were missing in the GCM ensemble mean. In contrast, these features were well simulated by the RCM, implying added values of RCM over GCM. The RCM bias map for DJF over central-western Borneo, Peninsular Malaysia, Sumatra and Java also indicate near zero bias as opposed to the underestimation of -4 to $-2 \mathrm{~mm} \mathrm{day}^{-1}$ in the GCM ensemble mean. During JJA, bias reduction is also featured in the RCM over mountainous areas of Laos, northern and central Vietnam, implying RCM's potential improvement over areas with complex topography (Fig. 5).
For further discussion on inter-model variations and consistency between RCMs and GCMs, biases maps for each RCM and GCM, relative to GPCC, are shown in the Supplementary Figures for DJF (Fig. S5; Fig. S6) and JJA (Fig. S7; Fig. S8). In Fig. S6 and Fig. S8, the biases of MRI-AGCM was not included due to the unavailability of the data during the time of the analysis. Generally, the RCM biases appear consistent to some driving GCMs especially for RCA4, ROM and PRECIS. Noticeably however, RegCM4 and WRF tended to overestimate the mean rainfall during DJF, e.g., wet biases are featured over Peninsular Malaysia, Borneo, Sumatra and Java in CNRMCM5 (RegCM4) as opposed to dry biases in CNRM-CM5 GCM. This is also the case for EC-EARTH (RegCM4), MPI-ESM-MR (RegCM4) and HadGEM2-ES (RegCM4). The HadGEM2-AO (WRF) show wet biases over northern Borneo and Vietnam as opposed to dry biases in the HadGEM2-AO GCM. The tendency for overestimation in RegCM4 simulations is also indicated during JJA (Fig. S7; Fig. S8). However, not all RegCM4 simulations produced wet biases and opposite to the driving GCMs. The biases in CSIRO-Mk3.6.0 (RegCM4) appear consistent with that of CSIRO-Mk3.6.0 GCM.

A detailed intercomparison of the RCM simulations is shown in the Taylor Diagram (Taylor 2001) in Fig. 6, summarising the performances of all members during the historical period against GPCC as a reference observation. Also shown are four other gridded observational products, i.e. CRU, APHRODITE, CHIRPS and TRMM. Despite differences among gridded observations, as previously highlighted in Juneng et al. (2016), Fig. 6 shows that these observation products are relatively close to each other, such that replacing GPCC with either TRMM, CHIRPS or APHRODITE may produce similar outcomes. However, since TRMM covers only 8 years (1998-2005) of the historical period, GPCC was chosen to provide a stable climatology of 30 years. The

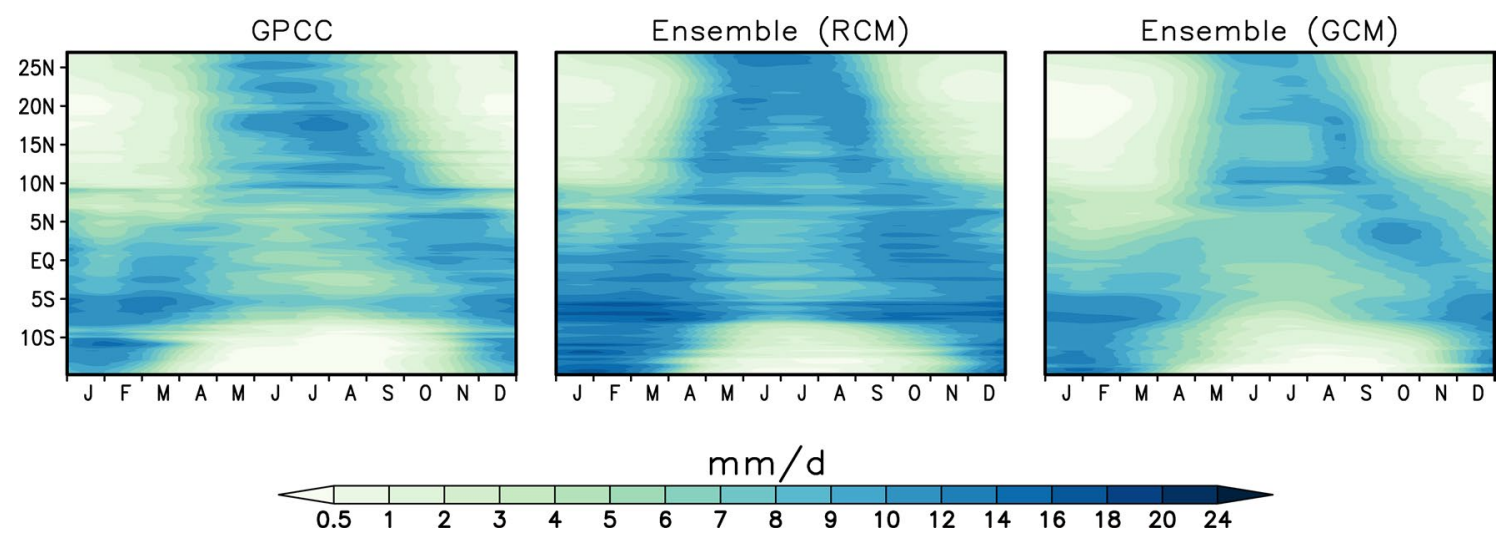

Fig. 4 Zonally-averaged annual cycle of precipitation of GPCC and the ensemble means of RCM and GCM, which were based on 12 and 8 members, respectively 

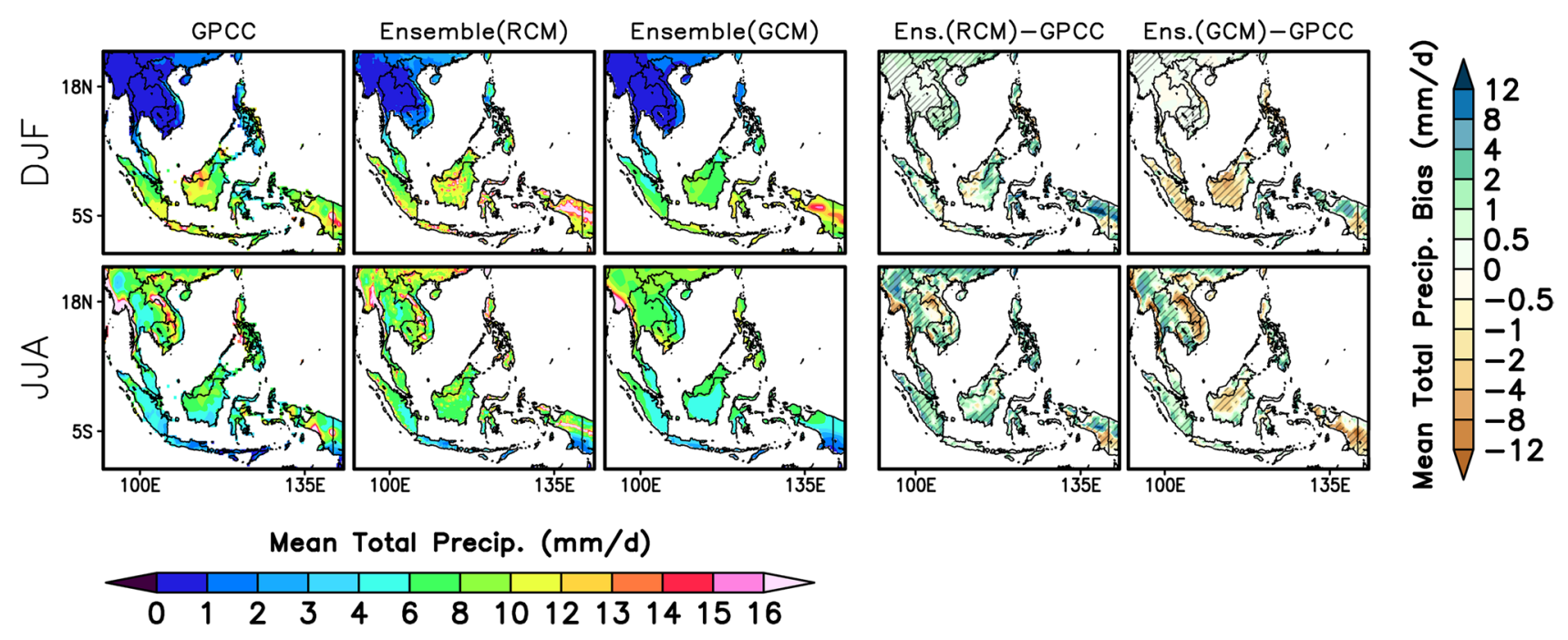

Fig. 5 Climatological seasonal mean precipitation for GPCC (left column), RCM ensemble mean (second column), GCM ensemble mean (third column), and respective biases (fourth and fifth columns)

use of GPCC as reference data for this study was in line with that of Tangang et al. (2019).

Figure 6 depicts inter-model variations where most models have root-mean-square difference (RMSD) greater than 1 for both seasons except for CCAM and MPI-ESM-LR (ROM). In terms of spatial correlation, the performances seem dependent on the season where most models registered correlations of $0.5-0.8$ for DJF, and $0.4-0.7$ for JJA. However, the correlation values of some models in JJA, e.g., EC-EARTH (RegCM4) and CSIRO-Mk3-6-0 (RegCM4), were lower than 0.4. For both seasons, the ensemble mean performed best with correlation values of 0.8 and 0.7 during DJF and JJA, respectively.

In CORDEX-SEA, one of the main interests was to evaluate how well the simulations at $25 \mathrm{~km}$ resolution capture the climatology of complex areas within the region. Figure 7 provides such information in terms of annual cycles of rainfall over the 20 sub-regions of interest (see Fig. 1). The rationale for selecting these 20 sub-regions was described in Juneng et al. (2016). In sub-regions covering many islands, e.g., R1, R2, R7, and R10, it would be important to analyse if simulations at $25 \mathrm{~km}$ resolution provide reasonable approximation. Figure 7 also shows the annual cycles of GPCC rainfall and the range of values from the RCM simulations. Generally, the RCMs overestimated rainfall in most sub-regions, which was likely caused by the wet biases in the RegCM4 simulations (Fig. S5; Fig. S7). In most sub-regions, the GPCC means were close to the lower bounds of the RCM simulations, implying the relatively large contribution of the RegCM4 simulations. in DJF (top row) and in JJA (bottom row). The ensemble means of RCM (GCM) were based on 12 (8) members. Hatching indicates differences (or biases) that are significant at $95 \%$ above random noise

Over the sub-regions of R15-R20 of mainland SEA, the ensemble mean performs extremely well especially over R18-R20. For these sub-regions, the annual cycles are characterized by a peak in rainfall during boreal summer and minimal rainfall during boreal winter (Tangang et al. 2019). However, the performance of an individual model can be different from that of the ensemble mean as indicated by the large difference between the lowest and the highest values, especially during JJA, which represent errors of RCMs and GCMs. Hence, this reiterates the requirement of having multi-model simulations and using the ensemble mean rather than an individual model (Valle et al. 2009).

In the Philippines (R1 and R2), relatively large wet biases are shown, particularly during April to October (Fig. 7), possibly due to the wet bias in the RegCM4 simulations. Other factors that may contribute include the inadequacy of the model's $25 \mathrm{~km} \times 25 \mathrm{~km}$ resolution to resolve the complex topography and island features, as well as difficulty in adequately simulating the monsoonal circulation and tropical cyclones, which both influence seasonal rainfall (Cruz and Sasaki 2017; Juneng et al. 2016). Over Borneo Island (R3, R4 and R5), the ensemble mean approximates the annual cycles reasonably well although a slight overestimation can be seen especially in R3 during February to April. Large inter-model variation can be seen throughout the year.

The overestimation by the ensemble mean is evident in the sub-regions of Sulawesi (R6), Maluku and West Papua (R7), Papua (R8) and Nusa Tenggara (R10). These subregions have been shown to have multiple climate regimes (Aldrian and Dwi Susanto 2003) and large rainfall variability 


\section{DJF}

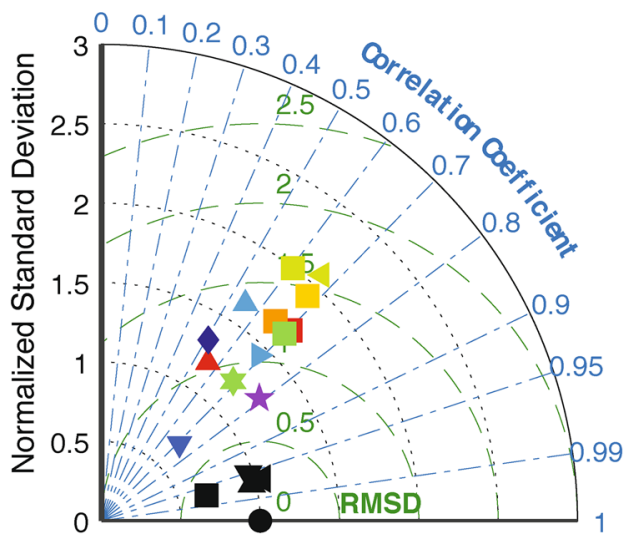

JJA

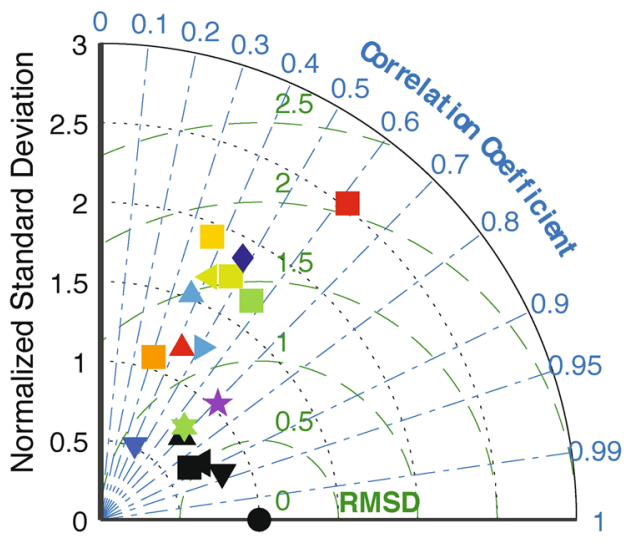

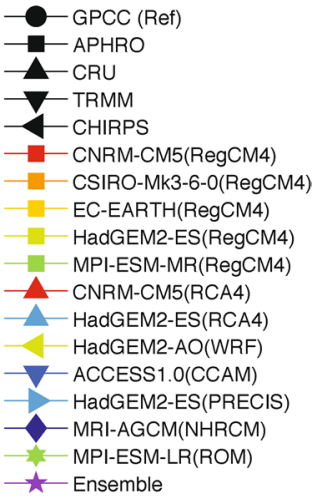

Fig. 6 Taylor diagram indicating the performances of individual RCMs and the ensemble mean against GPCC and other gridded precipitation products for DJF (left) and JJA (right)

(Aldrian et al. 2004). In addition to the RegCM4 tendency for wet simulations, the relatively large biases over these sub-regions could also be due to the models' inability to capture the precipitation processes due to the existence of many islands. Furthermore, a gridded dataset such as GPCC may not adequately represent rainfall in these sub-regions. On the other hand, the ensemble mean approximated the annual cycle much better over the southern part of Papua (R9), Java (R11) and the southern part of Sumatra (R12), with similar performances over northern Sumatra and western Peninsular Malaysia (R14). However, over eastern Peninsular Malaysia (R13), rainfall from all models, including the ensemble mean, tend to peak in October instead of November and December, when the maximum rainfall usually occurs due to cold surges and the Borneo vortex (Tangang et al. 2008, 2012; Chen et al. 2013a, b; Loh et al. 2016). Hence, such rainfall deficit could be due to the models' inability to correctly simulate the complex circulations and precipitation
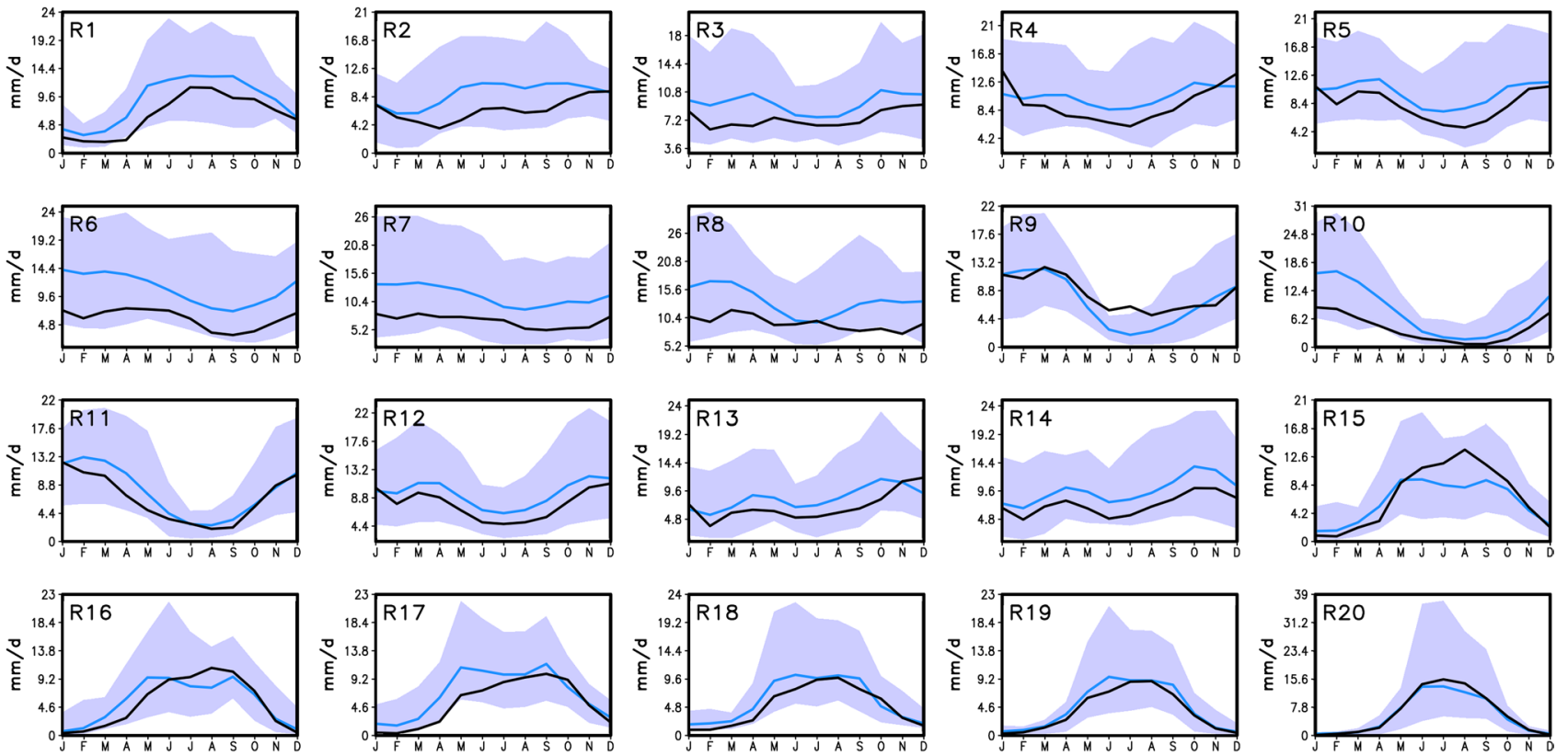

- Ensemble

- GPCC

Fig. 7 Historical annual cycles of precipitation based on GPCC (black) and the ensemble mean (blue) for the 20 sub-regions shown in Fig. 1. Gray shading indicates the range of values from individual models 
dynamics over this region. However, the analysis of this issue requires a detailed analysis of the circulation in each model, and is beyond the scope of this paper.

\subsection{Future projections}

\subsubsection{Regional circulation}

Figure 8 shows the projected changes in the RCM ensemble mean $850 \mathrm{hPa}$ seasonal winds for the early, mid and late twenty-first century periods for both RCP4.5 and RCP8.5. For RCP4.5, the ensemble means of early, mid and late twenty-first century periods were averaged from 8,8 and 7 members, respectively. For the RCP8.5, the corresponding number of ensemble members were 8, 11 and 7. Gradual changes over time are depicted for both RCPs and seasons with prominent changes by the end of the twenty-first century, especially for RCP8.5. During DJF, the directions of anomalous winds over north of the equator are largely opposite to the climatological winds (Fig. 2), implying a slight weakening of the winter monsoonal winds. Similarly, over Java Sea and south Indian Ocean, anomalous southeasterlies prevail implying weakened cross-equatorial and monsoonal winds during future periods, especially in the late twentyfirst century. On the other hand, anomalous westerlies are depicted over the eastern part of the domain. During JJA, stronger monsoonal winds can be seen over Indochina and northern South China Sea whereas winds are weaker over Java Sea. Overall, the projected low level winds indicated low level divergent flow over the Maritime Continent, largely consistent with the low level divergence shown in Fig. 9. Generally, enhanced divergence (convergence) over the Maritime Continent (Indochina) is projected in the future, especially during JJA (DJF).

\subsubsection{Seasonal precipitation}

The projected changes in seasonal mean precipitation from the RCM and GCM ensemble means, relative to the historical period 1976-2005 for the early, mid and late twenty-first century under RCP4.5 and RCP8.5 scenarios, are shown in Figs. 10 and 11, respectively. For RCP4.5, the RCM ensemble means of early, mid and late twentyfirst century periods were averaged from 9 members while for the RCP8.5, the number of ensemble members were 11,13 and 11 for early, mid and late twenty-first century, respectively. For all periods and RCPs, the GCM ensemble means were based on 8 members. The projected changes in GCM and RCM simulated mean rainfall are generally similar, although notable differences can be seen. Significant and robust increases of rainfall (10-20\%) are depicted during DJF over northern Thailand, Laos and northern Vietnam. The projected changes over Thailand is consistent with Tangang et al. (2019). Over northern Myanmar, while minimal changes are projected during early twentyfirst century for both RCPs and models, significant and robust increases (10-20\%) can be found by mid and late twenty-first century. However, during DJF over Cambodia and southern Vietnam, no significant and robust changes are projected except over Cambodia during mid twentyfirst century for RCP8.5. The projected changes during mid twenty-first century over Vietnam, Cambodia, Laos and eastern Thailand are generally consistent with that of the national report of Vietnam on future projected climate (Katzfey et al. 2014). In the Philippines, the projected changes show a slight wetting (drying) tendency in DJF (JJA) (Fig. 10), which is fairly consistent with the projected changes in Villafuerete et al. (2019) for mid twenty-first century under RCP8.5. In the GCM however, a slightly wetter condition is projected over the Philippines in JJA (Fig. 11).

While consistency between GCM and RCM is high during DJF for RCP4.5 in Indochina, some differences are depicted over the Maritime Continent, especially during mid and late twenty-first century. Significant and robust increases are projected over Sumatra, Kalimantan and Papua by the GCM in DJF but largely no changes in the RCM projection. This is also the case for RCP8.5 during late twenty-first century. Such inconsistencies can be caused by the modifications of the sign of change in the RCM compared to the driving GCMs. As shown in the Supplementary Figures of Fig. S9 and Fig. S10, drier condition is projected in some RCMs in contrast to the wetter condition in GCMs. For example, during DJF of late twenty-first century under RCP8.5, CNRM-CM5 (RegCM4) and MPI-ESM-MR (RegCM4) projected dry condition over Sumatra and Kalimantan (Fig. S9) whereas the CNRM-CM5 and MPI-ESM-MR GCMs indicated the opposite future change (Fig. S10). Such inconsistency between RCM and GCM is not uncommon and has also been reported in other studies (e.g., Dosio and Panitz 2016; Fernández et al. 2019).

There are some notable differences between projected rainfall in RCM and GCM for JJA under both RCPs (Figs. 10, 11). While both RCM and GCM show agreement on significant and robust reduction in rainfall (10-30\%) over Indonesian region, disagreement can be found in other areas. These include Indochina, northern Borneo, Peninsular Malaysia, Papua and the Philippines where mean rainfall increases are projected in the GCM but generally drier condition is indicated in RCM. Such inconsistencies can be attributed to the switching of the sign of changes in RCM 
Fig. 8 The RCM projected changes in low-level wind for early (left column), mid (middle column) and late twenty-first century (right column). The first and second rows (third and fourth rows) indicate the projected changes in DJF (JJA) for RCP4.5 and RCP8.5
Early Century

Mid Century
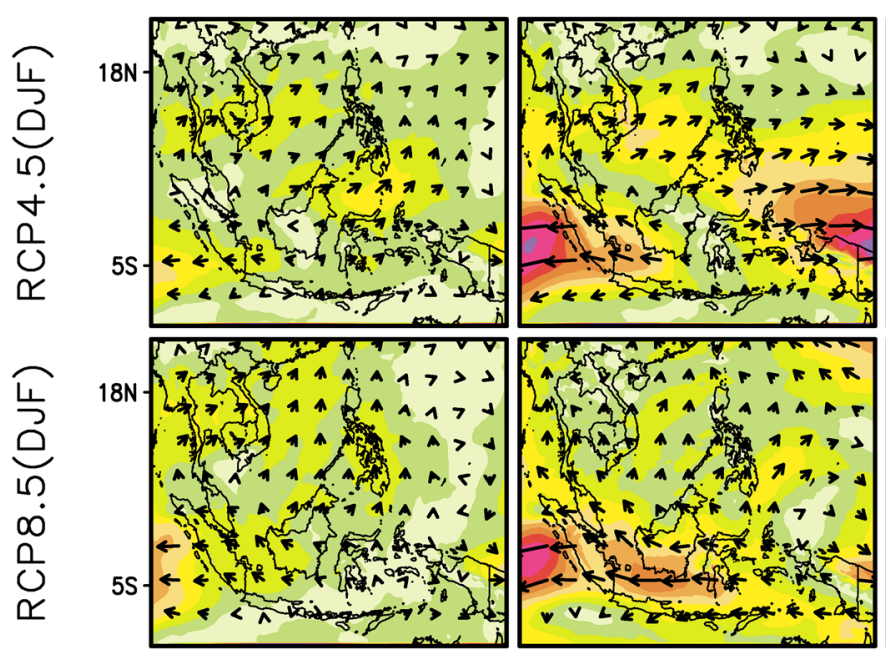

Late Century

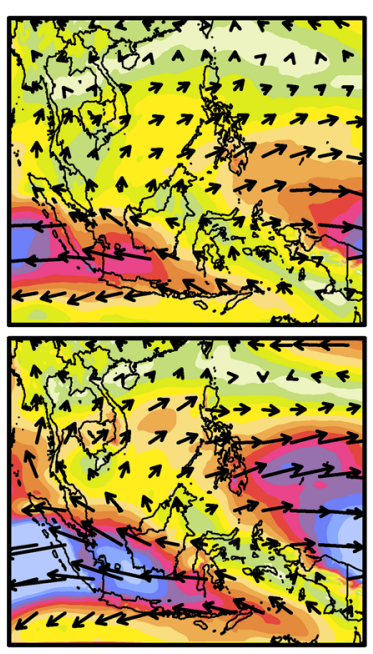

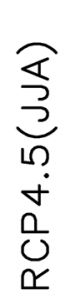
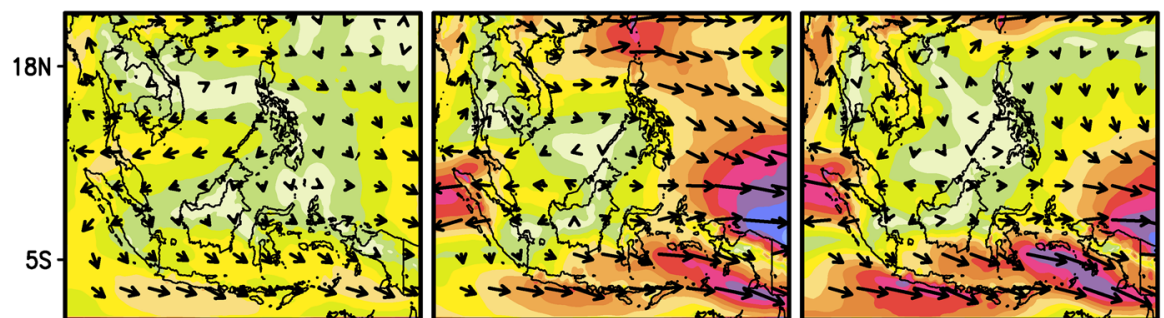

3
3
3
0
0
0
0
$x$
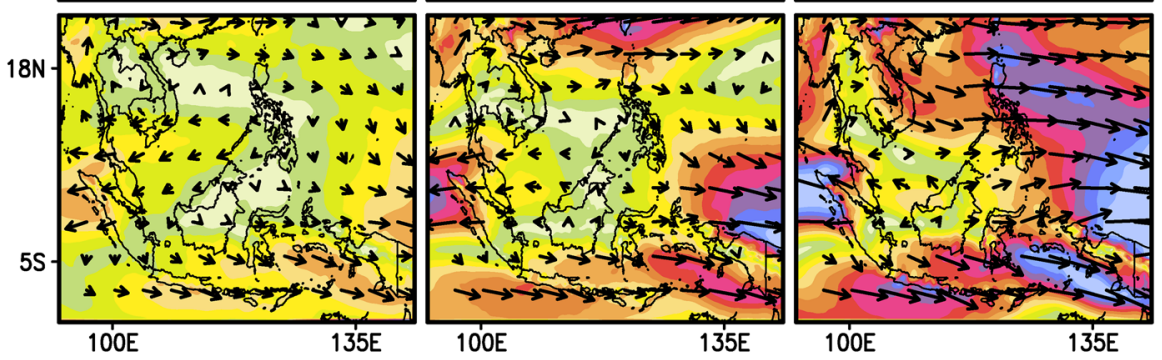

$850 \mathrm{hPa}$ Wind Changes Magnitude $(\mathrm{m} / \mathrm{s})$

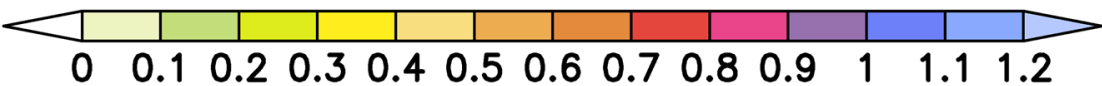

$1.5 \mathrm{~m} / \mathrm{s}$ compared to GCM (Fig. S11 and Fig. S12). Furthermore, it is not only RegCM4 that tended to switch the sign of change but RCA4 as well. However, over Myanmar for both RCPs and over northern Borneo, northwestern Thailand and Laos for RCP8.5, both GCM and RCM projections appeared consistent. While the projection of reduced rainfall over eastern Vietnam during mid twenty-first century for RCP8.5 is consistent with Katzfey et al. (2014), other areas indicated opposite changes.

\section{Discussion}

Due to the complex topography, archipelagic features and oceanic influences, regional climate simulation over Southeast Asia can be considered a very challenging task (e.g., Juneng et al. 2016; Ngo-Duc et al. 2017; Cruz et al. 2017; Ratna et al. 2017; Chung et al. 2018; Kang et al. 2019). Error and uncertainty in the simulations are difficult to reduce and can be attributed to the shortcomings in the RCMs (e.g., physical parameterizations, resolutions, etc.) and GCMs (as boundary forcing). A multi-model approach is used in the 
Fig. 9 As in Fig. 8 except for low-level divergence. Backslashes indicate robustness i.e., model agreement in the sign of change at $75 \%$ confidence level

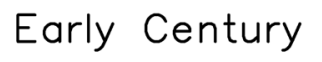

Mid Century

Late Century

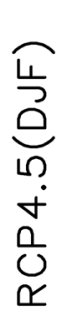
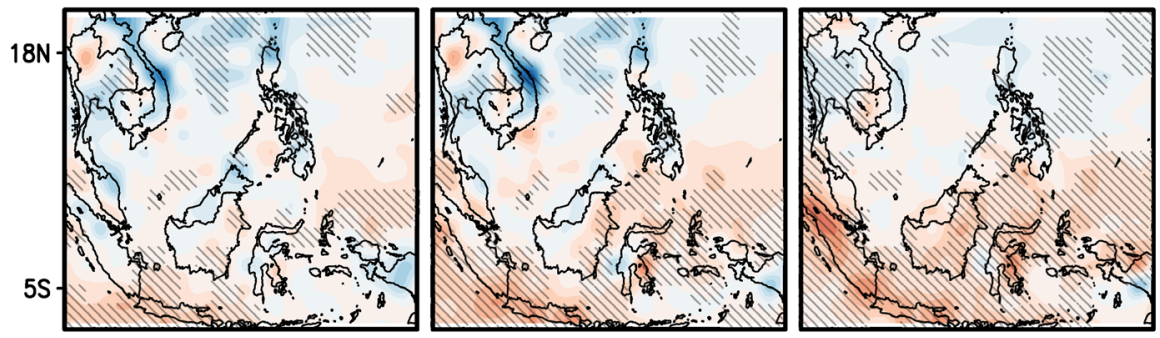

$\stackrel{2}{?}$
$\stackrel{0}{0}$
$\infty$
0
0
$\simeq$
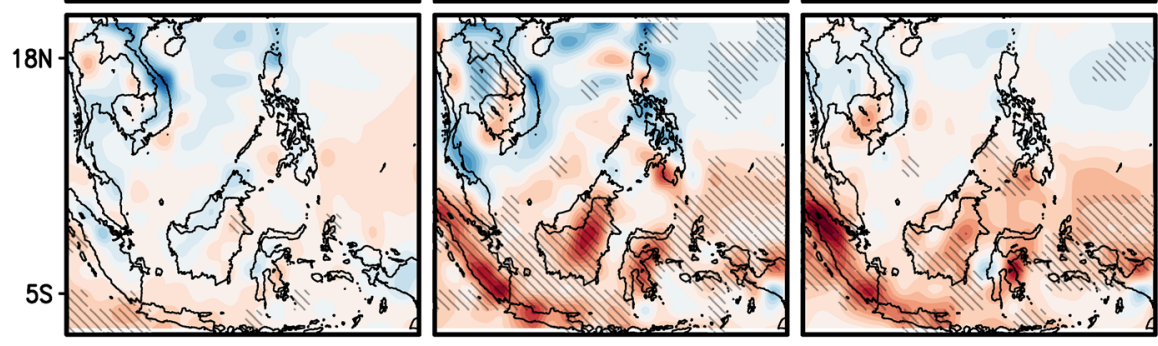

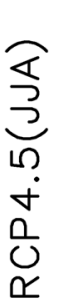
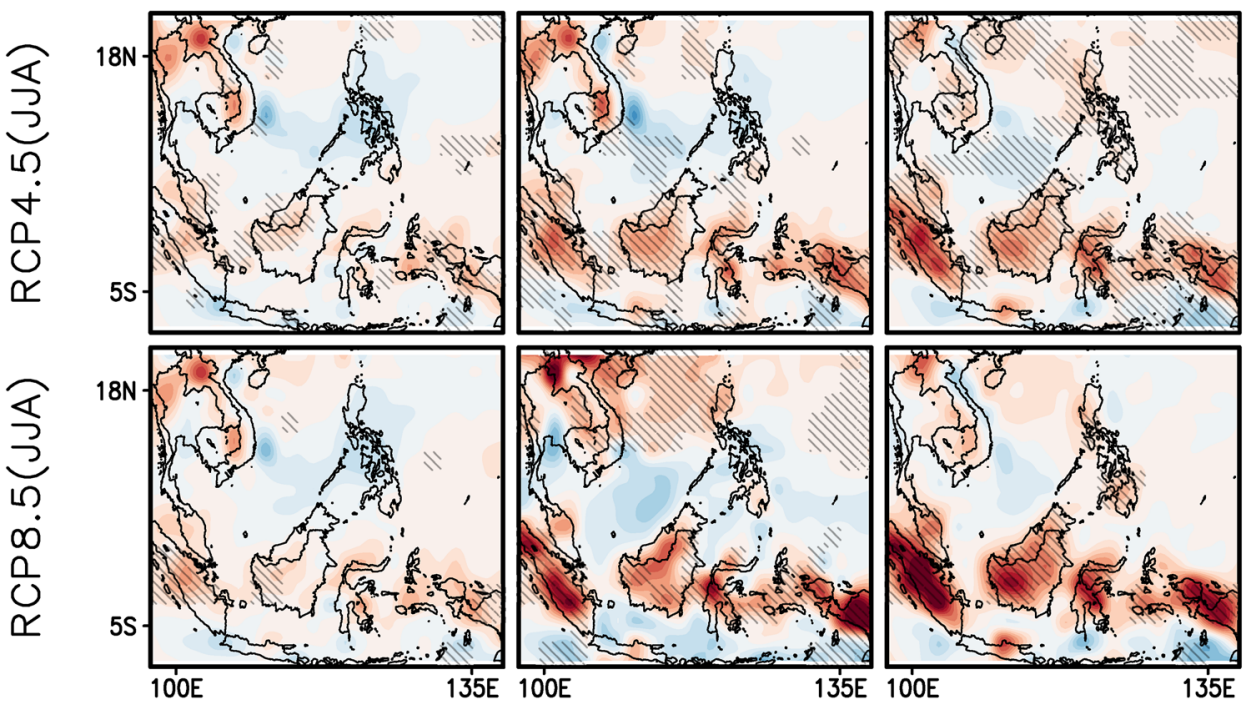

850hPa Divg. Changes Magnitude $\left(\times 10^{-6} \mathrm{~s}^{-1}\right)$

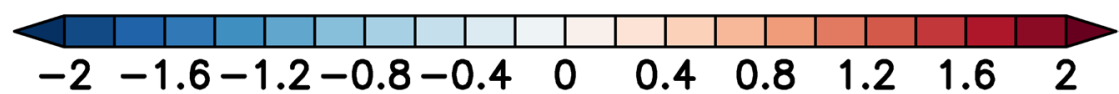

CORDEX-SEA simulations at $25 \mathrm{~km}$ horizontal resolution using $7 \mathrm{RCMs}$ and $11 \mathrm{GCMs}$, which allowed the uncertainty associated with the RCMs and GCMs to be sampled. The circulations (both low level winds and divergence field) and rainfall climatology were reasonably approximated by the ensemble means of RCMs and GCMs. Furthermore, the ensemble mean of RCMs showed added values by simulating some finer details in the rainfall spatial patterns. Nevertheless, consistent with Juneng et al. (2016), RegCM4 persistently produced wet simulations, contributing to the overall wet bias in the ensemble mean. In future work, RegCM4 may require further tuning and sensitivity analysis to reduce the wet biases. While the wet biases in the
RegCM4 simulations contributed to the large inter-model variations when evaluated at sub-regions, a higher resolution than $25 \mathrm{~km}$ may be required in future simulations to resolve the complex topography of many islands. Some synoptic regional circulations appear to be captured by the RCMs, which was missing in the GCMs, e.g., the Borneo vortex that brings high rainfall over Borneo (Chen et al. 2013a). However, the simulated rainfall over east of Peninsular Malaysia peak in October, not during November and December. This appears to indicate that the rainfall delivery mechanism, i.e., through cold surges and easterly waves (Tangang et al. 2012; Chen et al. 2013a), may not be well simulated in both GCM and RCM. 
Fig. 10 As in Fig. 9 except for precipitation, expressed as a percentage anomaly $(\%)$ relative to the mean in the historical period. Forward slashes indicate the changes that are significant at $90 \%$ level above random noise while backslashes show model agreement in the sign of change at $75 \%$ level of confidence

\section{Early Century Mid Century Late Century}
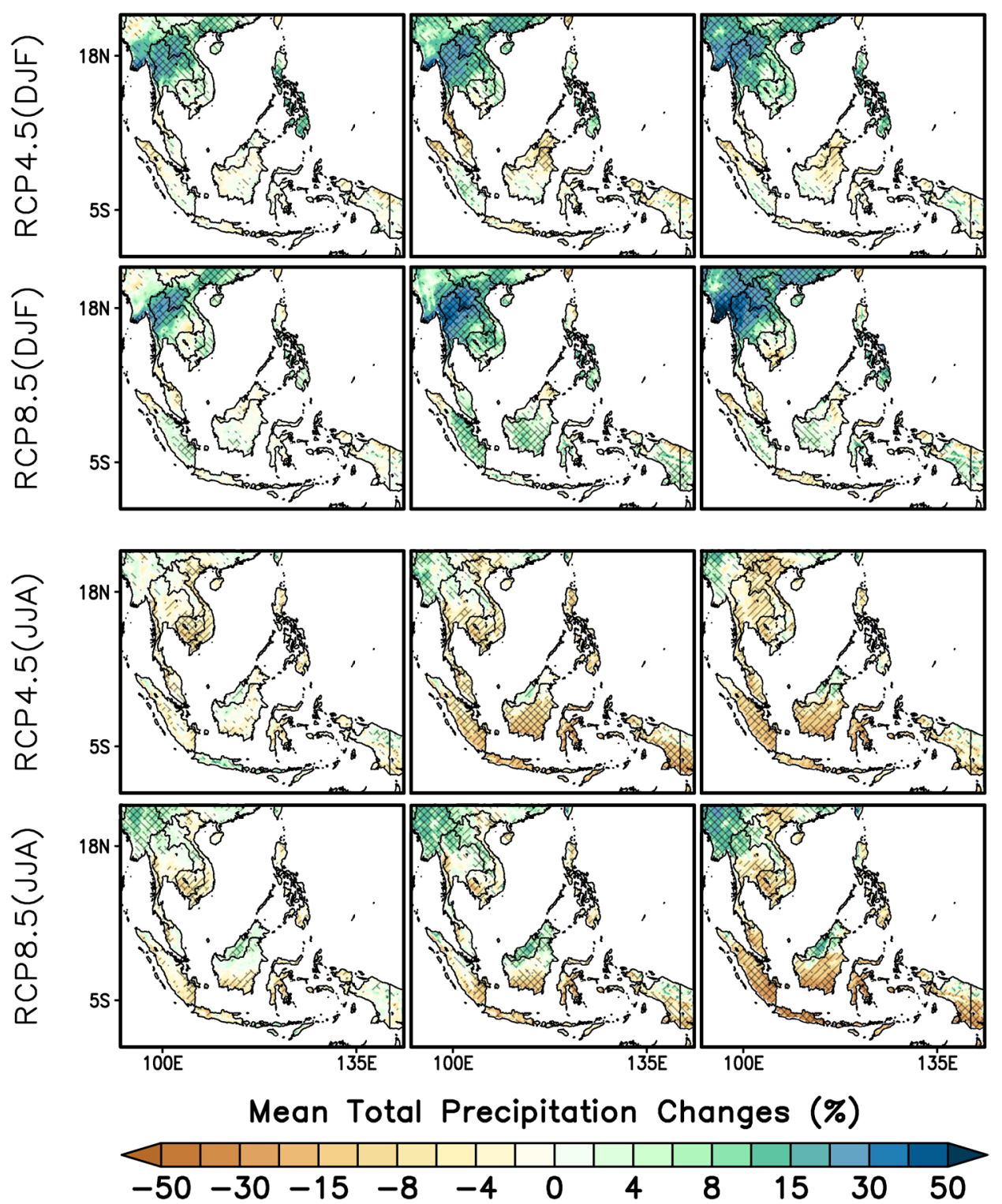

The projected changes in low-level winds and divergence fields indicated enhanced subsidence (rising motion) over the Maritime Continent (Indochina) especially during boreal summer (winter). Projected increased rainfall of 10-20\% over Indochina during DJF throughout the rest of the twentyfirst century, which is consistent in both RCM and GCM, would bring positive effects to various sectors including water resources, agriculture, power-generation etc., given the very low rainfall over this region during this season. At the same time, a reduction of $10-20 \%$ in mean rainfall during JJA over Cambodia, Vietnam and eastern Thailand could have serious implications especially for future agriculture and food production, which may have worldwide implications as these areas are currently considered as food-basket regions (Keskinen et al. 2010).
The most striking changes are the significant and robust mean rainfall reductions of 10-30\% over Indonesia during JJA, especially over Sumatra and Kalimantan by the middle and end of the twenty-first century under RCP4.5 and RCP8.5. This tendency for enhanced drying is consistent in both RCM and GCM simulations, which has also been highlighted in other studies (e.g. Kang et al. 2019; Giorgi et al. 2019; IPCC 2013), and can be associated with enhanced divergence and subsidence over the Maritime Continent (Fig. 9). While the causes may require further analysis, previous studies seem to indicate the enhanced subsidence can be associated with the deep tropical squeeze resulting from the equatorward contraction of the rising branch of the Hadley Circulation as the climate continues to warm ( $\mathrm{Fu} 2015)$. 
Fig. 11 As in Fig. 10 except for GCM

\section{Early Century Mid Century Late Century}

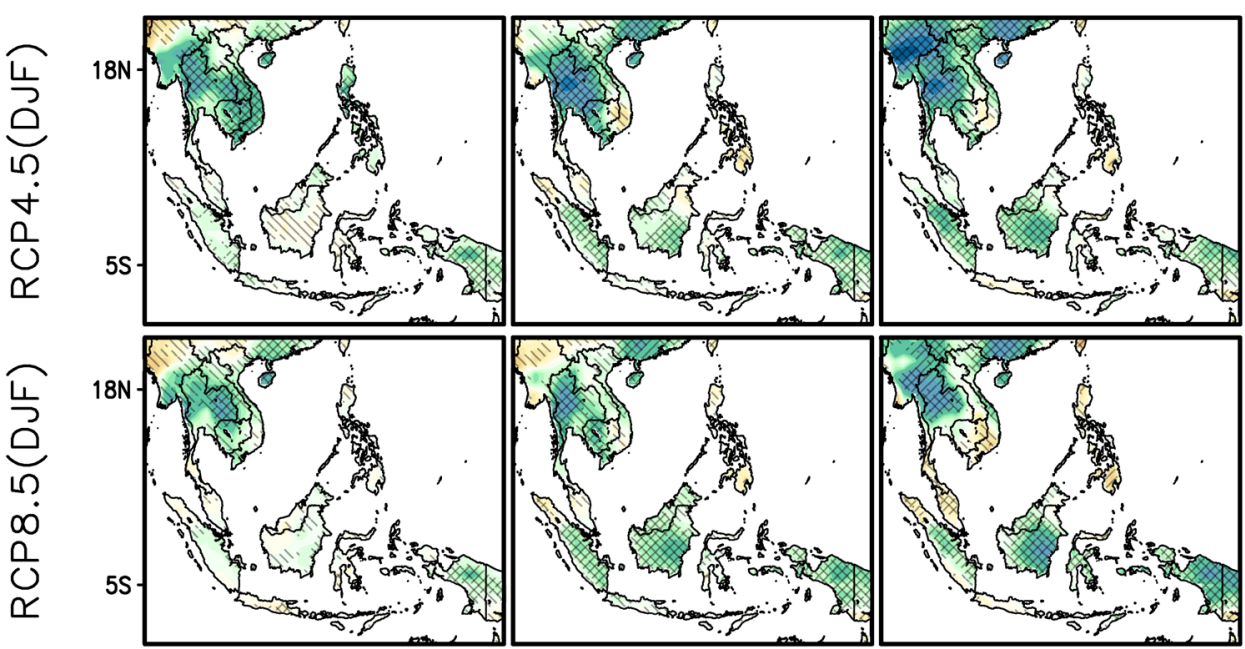

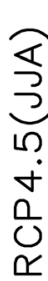
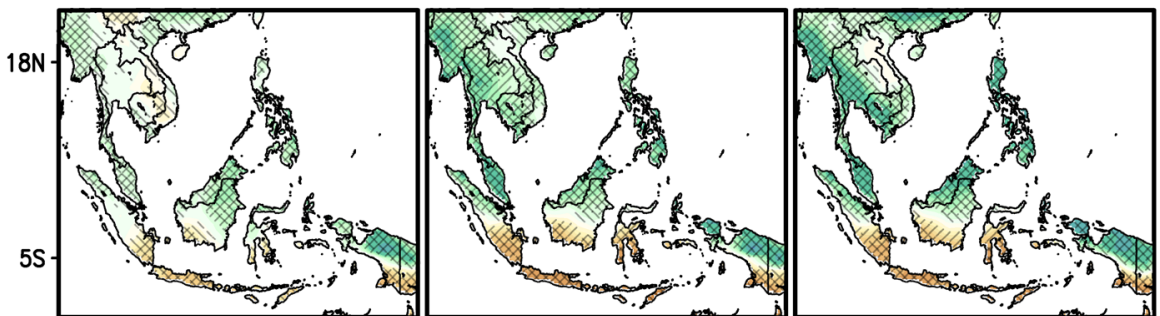

3
3
0
$\infty$
0
0
$\alpha$
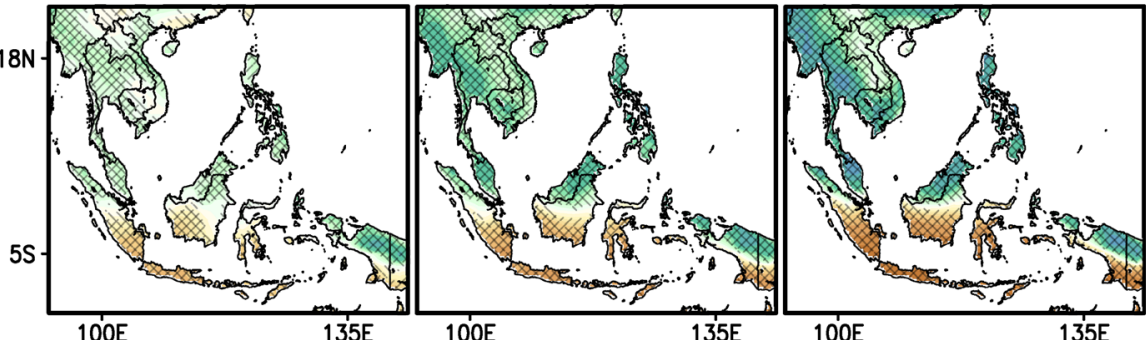

Mean Total Precipitation Changes (\%)

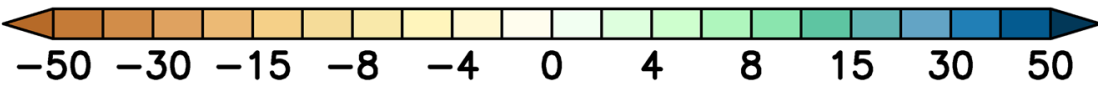

A recent study by Supari et al. (2020) indicated that the consecutive dry days (CDD) over Indonesia, especially Sumatra and Kalimantan, are projected to increase by more than 50\% for JJA and September-October-November ( $\mathrm{SON})$. Such a drying condition is experienced only inter-annually during El Niño events in the current climate (Juneng and Tangang 2005; Lestari et al. 2016; Supari et al. 2018), which usually provides favorable conditions for widespread peatland and forest fires, causing haze episodes that have significant economic impacts in Indonesia and surrounding countries (Tangang et al. 2010). With the likelihood of yearly occurrence of drought in future warmer periods, instead of inter-annually under El Niño conditions (Supari et al. 2018), the impacts of forest fires can be expected to worsen. Furthermore, the increasing likelihood for more frequent extreme El Niño events in future warmer periods (Cai et al. 2014) will exacerbate future challenges in mitigating drought and forest fires in Indonesia.

Information on uncertainty and ranges of projected changes in mean rainfall can be useful especially for users at the indicated 20 sub-regions. This information is provided in the Supplementary Figures of Fig. S13 and Fig. S14, showing plots of the projected surface temperature changes (in ${ }^{\circ} \mathrm{C}$ ) versus the projected rainfall changes (in \%) for all models including the ensemble mean. Only 11 ensemble members were available for the end of the twenty-first century projection (see Table 1). Although the ensemble mean shows no significant future changes in many sub-regions, the range of projections can be large. This represents the uncertainty in the projections, which is attributed to inter-model variations 
in both RCM and GCM. The users are recommended to consider these uncertainties when using CORDEX-SEA simulation products. The upper and lower limits of the projected changes in mean rainfall should be considered when estimating possible impacts of future climate change in those subregions (e.g. Daron et al. 2018). However, the use of individual model outputs for driving impact models may require bias-adjustment procedures (Ngai et al. 2017). In addition, large biases in some sub-regions within the archipelagic Maritime Continent (Fig. 7), tendency for wet biases for RegCM4 simulations (Fig. S5 to Fig. S8), and inconsistency on the sign of change with the forcing GCMs (Fig. S9 to Fig. S12) justify the need to fine tune the simulations in future undertaking. Furthermore, the use of recent CMIP Phase 6 (CMIP6) GCM simulations (Eyring et al. 2016) and higher spatial resolutions $(<25 \mathrm{~km})$ in climate simulations may reduce the biases and uncertainty.

\section{Conclusion}

With 7 RCMs and 11 forcing GCMs, the regional climate simulations of CORDEX-SEA represent the most comprehensive set of high-resolution regional climate simulations carried out over the Southeast Asia (SEA) region thus far. This paper examines the performance of these models in the historical period (1976-2005) and assesses future climate projection over SEA for early (2011-2040), mid (2041-2070) and late twenty-first century (2071-2099) periods under both RCP4.5 and RCP8.5 scenarios. With reasonably large number of ensemble members, which come from various RCMs, GCMs and constrained by different parameterization schemes, the set of simulations of CORDEX-SEA should provide robust estimates of future climate in this region, not just in terms of mean climate but also associated uncertainties. The following are key findings of the analysis:

(i) Seasonal low-level circulations of ERA-Interim during the historical period is captured reasonably well by the RCM ensemble mean. This is best reflected in both the $850 \mathrm{hPa}$ wind and divergence fields, where the monsoonal features of both fields have been simulated well by the models. However, biases exist, reflecting the inter-model variations among RCMs and GCM forcings.

(ii) The model ensemble mean captures well the spatial - temporal mean rainfall distribution over Southeast Asia, reflecting the models' ability to simulate monsoonal rainfall migration in the region associated with the Asian-Australian monsoon system. Compared with GCMs, RCMs showed added value, but significant and mostly wet biases reflect inter-model variations and overestimation in some models, primarily contributed by RegCM4. The ensemble mean simulated reasonably well the annual precipitation cycle of GPCC over the 20 sub-regions, especially over Indochina, except over some sub-regions comprising many islands in the Maritime Continent.

(iii) Projected low-level circulations show low-level divergent flow over the Maritime Continent, causing enhanced subsidence in this region especially during JJA, and rising motion over Indochina.

(iv) Enhanced mean rainfall of 10-20\% are projected over Indochina during DJF for both RCPs throughout the twenty-first century. During JJA, enhanced drying condition and mean rainfall reductions of 10-30\% are projected over the Indonesian region.

Overall, in addition to previous but limited studies (Kang et al. 2019; Rahmat et al. 2014; Katzfey et al. 2014; Villafuerete et al. 2019 and other initiatives at national levels), this study advances the scientific understanding of future climate change over the SEA region. Future studies should focus on reducing the biases in models, and to analyse whether individual models capture the complex and multiscale circulations over the region. In order to facilitate future studies and data dissemination, the model outputs of CORDEX-SEA are archived in a dedicated data portal called the Southeast Asia Regional Climate Change Information System (SARCCIS), hosted by the Ramkhamhaeng University Center for Regional Climate Change and Renewable Energy (RU-CORE) in Bangkok, Thailand (https://www.rucore.ru. ac.th/SARCCIS). This data archive is linked to the Earth System Grid Federation (ESGF).

Acknowledgements This research is funded by the Asia-Pacific Network for Global Change Research (ARCP2013-17NMY-Tangang, ARCP2014-07CMY-Tangang, ARCP2015-04CMY-Tangang) with additional support from Universiti Kebangsaan Malaysia (ICONIC-2013-001), Malaysian MOHE FRGS/1/2017/WAB05/ UKM/01/2, Thailand Research Fund (RDG5630019), National Research Council of Thailand (2557-73 and 2559-226), BMKG Research Fund (National Budget for FY 2013-2018), Department of Science and Technology-Philippine Council for Industry, Energy, and Emerging Technology Research and Development (DOST-PCIEERD) of the Philippines, JSPS KAKENHI Grant Number 15F15028 and APEC Climate Center. F. Cruz was an International Research Fellow of the Japan Society for the Promotion of Science. D. Sein was supported by the Russian Science Foundation (RSF-DST project No. 19-47-02015) and the state assignment of Russia (theme No. 01492019-0015). Thanh Ngo-Duc is supported by the Vietnam National Foundation for Science and Technology Development (NAFOSTED) under Grant 105.06-2018.05 and by Hanoi Forum (code HNQT/ QL/01.18). Pankaj Kumar is supported by the Department of Science and Technology (DST), Govt. of India, grant number DST/INT/RUS/ RSF/P-33/G. 
Open Access This article is licensed under a Creative Commons Attribution 4.0 International License, which permits use, sharing, adaptation, distribution and reproduction in any medium or format, as long as you give appropriate credit to the original author(s) and the source, provide a link to the Creative Commons licence, and indicate if changes were made. The images or other third party material in this article are included in the article's Creative Commons licence, unless indicated otherwise in a credit line to the material. If material is not included in the article's Creative Commons licence and your intended use is not permitted by statutory regulation or exceeds the permitted use, you will need to obtain permission directly from the copyright holder. To view a copy of this licence, visit http://creativecommons.org/licenses/by/4.0/.

\section{References}

Aldrian E, Dwi Susanto R (2003) Identification of three dominant rainfall regions within Indonesia and their relationship to sea surface temperature. Int J Climatol 23:1435-1452. https://doi. org/10.1002/joc. 950

Aldrian E, Dümenil-Gates L, Jacob D, Podzun R, Gunawan D (2004) Long-term simulation of Indonesian rainfall with the MPI regional model. Climate Dyn 22:795-814. https://doi. org/10.1007/s00382-004-0418-9

Baez JC, Tweed D (2013) Monte Carlo Methods In Climate Science. Math Horiz 21(2):5-8. https://doi.org/10.4169/mathhorizo ns.21.2.5

Beljaars ACM, Holtslag AAM (1991) Flux parameterization over land surfaces for atmospheric models. J Appl Meteorol Climatol 30:327-341. https://doi.org/10.1175/15200450(1991)030<0327:Fpolsf > 2.0.Co;2

Birch CE, Webster S, Peatman SC, Parker DJ, Matthews AJ, Li Y, Hassim MEE (2016) Scale interactions between the MJO and the Western Maritime Continent. J Climate 29:2471-2492. https:// doi.org/10.1175/jcli-d-15-0557.1

Cai W, Borlace S, Lengaigne M, van Rensch P, Collins M, Vecchi G, Timmermann A, Santoso A, McPhaden MJ, Wu L, England MH, Wang G, Guilyardi E, Jin FF (2014) Increasing frequency of extreme El Niño events due to greenhouse warming. Nat Climate Change. https://doi.org/10.1038/NCLIMATE2100

Chang C-P, Wang Z, McBride J, Liu C-H (2005) Annual cycle of Southeast Asia-maritime continent rainfall and the asymmetric monsoon transition. J Climate 18:287-301. https://doi. org/10.1175/jcli-3257.1

Chen J-D, Yen M-C, Matsumoto J (2013a) The winter rainfall of Malaysia. J Climate 26:936-958

Chen J-D, Yen M-C, Matsumoto J (2013b) Interannual variation of the winter rainfall in Malaysia. J Climate 26:4630-4648

Christensen J et al (2007) Regional climate projections. Climate change 2007: the physical science basis. In: Contribution of working group I to the fourth assessment report of the intergovernmental panel on climate change, pp 847-940

Chung JX, Juneng L, Tangang F, Jamaluddin AF (2018) Performances of BATS and CLM land-surface schemes in RegCM4 in simulating precipitation over CORDEX Southeast Asia domain. Int J Climatol 38:794-810. https://doi.org/10.1002/joc.5211

Collins W et al (2004) Description of the NCAR Community Atmosphere Model (CAM 3.0) (No. NCAR/TN-464+STR). https://doi. org/10.5065/D63N21CH

Cruz FT, Sasaki H (2017) Simulation of present climate over southeast Asia using the non-hydrostatic regional climate model. SOLA 13:13-18. https://doi.org/10.2151/sola.2017-003

Cruz F, Sasaki H, Narisma G (2016) Assessing the sensitivity of the non-hydrostatic regional climate model to boundary conditions and convective schemes over the Philippines. J Meteorol Soc Japan Ser II 94A:165-179. https://doi.org/10.2151/ jmsj.2015-059

Cruz F, Narisma G, Dado J, Singhruck P, Tangang F, Linarka U, Aldrian E et al (2017) Sensitivity of temperature to physical parameterization schemes of RegCM4 over the CORDEXSoutheast Asia region. Int J Climatol 37:5139-5153. https://doi. org/10.1002/joc.5151

Cuxart J, Bougeault P, Redelsperger J-L (2000) A turbulence scheme allowing for mesoscale and large-eddy simulations. Q J R Meteorol Soc 126:1-30. https://doi.org/10.1002/qj.49712656202

Daron J et al (2018) Providing future climate projections using multiple models and methods: insights from the Philippines. Climat Change 148:187-203. https://doi.org/10.1007/s1058 4-018-2183-5

Dee DP et al (2011) The ERA-Interim reanalysis: configuration and performance of the data assimilation system. Q J R Meteorol Soc 137:553-597. https://doi.org/10.1002/qj.828

Dickinson RE, Henderson-Sellers A, Kennedy PJ (1993) Biosphereatmosphere transfer scheme (BATS) Version 1e as Coupled to the NCAR Community Climate Model. https://doi.org/10.5065/ D67W6959

Dosio A, Panitz HJ (2016) Climate change projections for CORDEXAfrica with COSMO-CLM regional climate model and differences with the driving global climate models. Climate Dyn 46(5-6):1599-1625. https://doi.org/10.1007/s00382-015-2664-4

Edwards J, Slingo A (1996) Studies with a flexible new radiation code. Part I: choosing a configuration for a large-scale model. Q J R Meteorol Soc 122:689-719

Emanuel KA, Živković-Rothman M (1999) Development and evaluation of a convection scheme for use in climate models. J Atmos Sci 56:1766-1782. https://doi.org/10.1175/15200469(1999)056<1766:Daeoac > 2.0.Co;2

Essery R, Best M, Cox P (2001) Moses 2.2 technical documentation. Technical report 30. Hadley Centre. https://www.metoffice.gov. uk/media/pdf/9/j/HCTN_30

Eyring V, Bony S, Meehl GA, Senior CA, Stevens B, Stouffer RJ, Taylor KE (2016) Overview of the Coupled Model Intercomparison Project Phase 6 (CMIP6) experimental design and organization. Geosci Model Dev 9:937-1958. https://doi.org/10.5194/ gmd-9-1937-2016

Fernández J, Frías MD, Cabos WD, Cofiño AS, Domínguez M, Fita L, Gaertner MA, García-Díez M, Gutiérrez JM, Jiménez-Guerrero P, Liguori G (2019) Consistency of climate change projections from multiple global and regional model intercomparison projects. Climate Dyn 52(1-2):1139-1156

Fouquart Y, Bonnel B (1980) Computations of solar heating of the earth's atmosphere-a new parameterization. Beitrage zur Physik der Atmosphare 53:35-62

Fowler HJ, Blenkinsop S, Tebaldi C (2007) Linking climate change modelling to impacts studies: recent advances in downscaling techniques for hydrological modelling. Int J Climatol 27:15471578. https://doi.org/10.1002/joc. 1556

Fu R (2015) Global warming-accelerated drying in the tropics. Proc Natl Acad Sci 112:3593. https://doi.org/10.1073/pnas.15032 31112

Funk C et al (2015) The climate hazards infrared precipitation with stations-a new environmental record for monitoring extremes. Sci Data 2:150066. https://doi.org/10.1038/sdata.2015.66

$\mathrm{Ge} F$ et al (2019) Risks of precipitation extremes over Southeast Asia: does $1.5^{\circ} \mathrm{C}$ or $2{ }^{\circ} \mathrm{C}$ global warming make a difference? Environ Res Lett 14:044015. https://doi.org/10.1088/1748-9326/aaff7e

Giorgi F, Mearns LO (1991) Approaches to the simulation of regional climate change: a review. Rev Geophys 29:191-216. https://doi. org/10.1029/90rg02636 
Giorgi F, Jones C, Asrar GR (2009) Addressing climate information needs at the regional level: the CORDEX framework. Bull World Meteorol Organ 58:175-183

Giorgi F, Raffaele F, Coppola E (2019) The response of precipitation characteristics to global warming from climate projections. Earth Syst Dyn 10:73-89. https://doi.org/10.5194/esd-10-73-2019

Gregory JM (1999) Representation of the radiative effect of convective anvils. Hadley Centre Technical Note7. Met Office, Exeter

Hagemann S (2002) An improved land surface parameter dataset for global and regional climate models. Tech Rep. https://doi. org/10.17617/2.2344576

Herrmann M, Ngo-Duc T, Trinh-Tuan L (2020) Impact of climate change on sea surface wind in Southeast Asia, from climatological average to extreme events: results from a RegCM4 dynamical downscaling of CNRM-CM5 in the CORDEX-SEA framework. Climatee Dyn 54:2101-2134. https://doi.org/10.1007/s0038 2-019-05103-6

Hewitson BC, Crane RG (1996) Climate downscaling: techniques and application. Climate Res 07:85-95

Hidayat R, Kizu S (2010) Influence of the Madden-Julian Oscillation on Indonesian rainfall variability in austral summer. Int J Climatol 30:1816-1825. https://doi.org/10.1002/joc.2005

Hijioka Y, Lasco R, Surjan A, Pereira J (2014) Asia. In: Climate change 2014: impacts, adaptation, and vulnerability. Part B Regional aspects. Contribution of working group II to the Fifth Assessment Report of the IPCC. Cambridge University Press, Cambridge

Hill SA, Ming Y, Zhao M (2018) Robust responses of the Sahelian hydrological cycle to global warming. J Climate 31:9793-9814. https://doi.org/10.1175/jcli-d-18-0238.1

Hirai M, Ohizumi M (2004) Development of a new land-surface model for JMA-GSM. Bull Am Meteorol Soc 85:2737-2743

Holtslag AAM, Boville BA (1993) Local versus non-local boundary layer diffusion in a global climate model. J Climate 6:1825-1842

Holtslag AAM, Bruijn EIFD, Pan H-L (1990) A high resolution air mass transformation model for short-range weather forecasting. Mon Weather Rev 118:1561-1575. https://doi.org/10.1175/15200493(1990)118<1561:Ahramt>2.0.Co;2

Hong S-Y, Dudhia J, Chen S-H (2004) A revised approach to ice microphysical processes for the bulk parameterization of clouds and precipitation. Mon Weather Rev 132:103-120. https://doi. org/10.1175/1520-0493(2004)132<0103:Aratim>2.0.Co;2

Hong S-Y, Kim J-H, Lim J-o, Dudhia J (2006) The WRF single moment microphysics scheme (WSM). J Korean Meteorol Soc 42:129-151

Huffman GJ et al (2007) The TRMM multisatellite precipitation analysis (TMPA): quasi-global, multiyear, combined-sensor precipitation estimates at fine scales. J Hydrometeorol 8:38-55. https:// doi.org/10.1175/jhm560.1

IPCC (2013) Climate change 2013: the physical science basis. In: Contribution of working group I to the fifth assessment report of the intergovernmental panel on climate change. Cambridge University Press, Cambridge. https://doi.org/10.1017/CBO97 81107415324

Jones RG, Noguer M, Hassell DC, Hudson D, Wilson SS, Jenkins GJ, Mitchell JFB (2004) Generating high resolution climate change scenarios using PRECIS. Met Office Hadley Centre, Exeter, p 40

Juneng L, Tangang FT (2005) Evolution of ENSO-related rainfall anomalies in Southeast Asia region and its relationship with atmosphere-ocean variations in Indo-Pacific sector. Climate Dyn 25:337-350. https://doi.org/10.1007/s00382-005-0031-6

Juneng L et al (2016) Sensitivity of Southeast Asia rainfall simulations to cumulus and air-sea flux parameterizations in RegCM4. Climate Res 69:59-77

Kain JS, Fritsch JM (1990) A one-dimensional entraining/detraining plume model and its application in convective parameterization.
J Atmos Sci 47:2784-2802. https://doi.org/10.1175/15200469(1990)047<2784:Aodepm>2.0.Co;2

Kain JS, Fritsch JM (1993) Convective parameterization for mesoscale models: the Kain-Fritsch scheme. In: Emanuel KA, Raymond DJ (eds) The representation of cumulus convection in numerical models. American Meteorological Society, Boston, pp 165-170. https://doi.org/10.1007/978-1-935704-13-3_16

Kang S, Im E-S, Eltahir EAB (2019) Future climate change enhances rainfall seasonality in a regional model of western Maritime Continent. Climate Dyn 52:747-764. https://doi.org/10.1007/s0038 2-018-4164-9

Katzfey JJ, McGregor JL, Suppiah R (2014) High-resolution climate projections for Vietnam: technical report. CSIRO, Australia, $\mathrm{p}$ 266

Katzfey J et al (2016) High-resolution simulations for Vietnam - methodology and evaluation of current climate. Asia Pac J Atmos Sci 52:91-106. https://doi.org/10.1007/s13143-016-0011-2

Keskinen M, Chinvanno S, Kummu M, Nuorteva P, Snidvongs A, Olli V, Västilä K (2010) Climate change and water resources in the Lower Mekong River Basin: Putting adaptation into the context. J Water Climate Change. https://doi.org/10.2166/wcc.2010.009

Kiehl J, Hack J, Bonan G, Boville B, Briegleb B, Williamson D, Rasch P (1996) Description of the NCAR community climate model (CCM3). NCAR Technical Note

Kim D, Kim H, Lee M-I (2017) Why does the MJO detour the Maritime Continent during austral summer? Geophys Res Lett 44:2579-2587. https://doi.org/10.1002/2017g1072643

Kitagawa H (2000) Radiation processes. Sep Vol Annu Rep NPD 46:16-31

Kowalczyk EA, Garratt JR, Krummel PB (1994) Implementation of a soil-canopy scheme into the CSIRO GCM-regional aspects of the model response. Melbourne. https://doi. org/10.4225/08/58655114bd171

Lestari S, Hamada J-I, Syamsudin F, Sunaryo MJ, Yamanaka MD (2016) ENSO influences on rainfall extremes around Sulawesi and Maluku Islands in the Eastern Indonesian Maritime Continent. SOLA 12:37-41. https://doi.org/10.2151/sola.2016-008

Limsakul A, Singhruck P, Wang L (2017) Climatology and spatiotemporal variability of wintertime total and extreme rainfall in Thailand during 1970-2012. EnvironmentAsia 10:162-176. https://doi.org/10.14456/ea.2017.31

Lin Y-L, Farley RD, Orville HD (1983) Bulk parameterization of the snow field in a cloud model. J Climate Appl Meteorol 22:1065-1092

Loh JL, Tangang F, Juneng L, Hein D, Lee D-I (2016) Projected rainfall and temperature changes over Malaysia at the end of the 21 st century based on PRECIS modelling system. Asia Pac J Atmos Sci 52:191-208. https://doi.org/10.1007/s1314 3-016-0019-7

Lohmann U, Roeckner E (1996) Design and performance of a new cloud microphysics scheme developed for the ECHAM general circulation model. Climate Dyn 12:557-572. https://doi. org/10.1007/bf00207939

Louis J-F (1979) A parametric model of vertical eddy fluxes in the atmosphere. Bound Layer Meteorol 17:187-202. https://doi. org/10.1007/bf00117978

Luis AJ, Pandey PC (2003) Relationship between surface atmospheric convergence over Indian Ocean and Indian rainfall. Geophys Res Lett 31:L06208. https://doi.org/10.1029/2003G L019357

Manomaiphiboon K, Octaviani M, Torsri K, Towprayoon S (2013) Projected changes in means and extremes of temperature and precipitation over Thailand under three future emissions scenarios. Climate Res 58:97-115

Massey N et al (2015) weather@home_development and validation of a very large ensemble modelling system for probabilistic 
event attribution. Q J R Meteorol Soc 141:1528-1545. https:// doi.org/10.1002/qj.2455

McGregor JL (1997) Regional climate modelling. Meteorol Atmos Phys 63:105-117. https://doi.org/10.1007/bf01025367

McGregor JL (2003) A new convection scheme using simple closure. In: Paper presented at the Current issues in the parameterization of convection: extended abstracts of presentations at the fifteenth annual BMRC Modelling Workshop, Bureau of Meteorology Research Centre

McGregor JL (2005a) C-CAM geometric aspects and dynamical formulation. Aspendale

McGregor JL (2005b) Geostrophic adjustment for reversibly staggered grids. Mon Weather Rev 133:1119-1128. https://doi. org/10.1175/mwr2908.1

McGregor JL (2015) Recent developments in variable-resolution global climate modelling. Clim Change 129:369-380. https:// doi.org/10.1007/s10584-013-0866-5

McGregor JL, Walsh KJ, Katzfey JJ (1993) Nested modelling for regional climate studies. In: Modelling change in environmental systems, pp 367-386

McGregor JL, Nguyen KC, Kirono DGC, Katzfey JJ (2016) Highresolution climate projections for the islands of Lombok and Sumbawa, Nusa Tenggara Barat Province, Indonesia: challenges and implications. Climate Risk Manag 12:32-44. https://doi. org/10.1016/j.crm.2015.10.001

McSweeney CF, Jones RG, Lee RW, Rowell DP (2015) Selecting CMIP5 GCMs for downscaling over multiple regions. Climate Dyn 44:3237-3260. https://doi.org/10.1007/s00382-014-2418-8

Meehl GA, Boer GJ, Covey C, Latif M, Stouffer RJ (2000) The coupled model intercomparison project (CMIP). Bull Am Meteorol Soc 81:313-318

Mitchell TD, Jones PD (2005) An improved method of constructing a database of monthly climate observations and associated high-resolution grids. Int J Climatol 25:693-712. https://doi. org/10.1002/joc. 1181

Morcrette J-J, Fouquart Y (1986) Pressure and temperature dependence of the absorption in longwave radiation parameterizations. Beitrage zur Physik der Atmosphare 59:455-469

Murakami M (1990) Numerical modeling of dynamical and microphysical evolution of an isolated convective cloud - the 19 July 1981 CCOPE Cloud. J Meteorol Soc Japan Ser II 68:107-128. https://doi.org/10.2151/jmsj1965.68.2_107

Murphy J (1999) An evaluation of statistical and dynamical techniques for downscaling local climate. J Climate 12:2256-2284. https:// doi.org/10.1175/1520-0442(1999)012<2256:Aeosad >2.0.Co;2

NAHRIM (2006) Final Report. Study of the impact of climate change on the hydrologic regime and water resources of Peninsular Malaysia. National Hydraulic Research Institute of Malaysia (NAHRIM) and California Hydrolic Research Laboratory (CHRL), United States

Ngai ST, Tangang F, Juneng L (2017) Bias correction of global and regional simulated daily precipitation and surface mean temperature over Southeast Asia using quantile mapping method. Glob Planet Change 149:79-90. https://doi.org/10.1016/j.glopl acha.2016.12.009

Ngo-Duc T, Kieu C, Thatcher M, Nguyen-Le D, Phan-Van T (2014) Climate projections for Vietnam based on regional climate models. Climate Res 60:199-213

Ngo-Duc T et al (2017) Performance evaluation of RegCM4 in simulating extreme rainfall and temperature indices over the CORDEXSoutheast Asia region. Int J Climatol 37:1634-1647. https://doi. org/10.1002/joc. 4803

Nguyen KC, McGregor JL (2009) Modelling the Asian summer monsoon using CCAM. Climate Dyn 32:219-236. https://doi. org/10.1007/s00382-008-0492-5
Nikulin G et al (2012) Precipitation climatology in an ensemble of CORDEX-Africa regional climate simulations. J Climate 25:6057-6078. https://doi.org/10.1175/jcli-d-11-00375.1

Nordeng TE (1994) Extended versions of the convective parametrization scheme at ECMWF and their impact on the mean and transient activity of the model in the tropics. ECMWF, Shinfield Park

Pal JS, Small EE, Eltahir EAB (2000) Simulation of regional-scale water and energy budgets: representation of subgrid cloud and precipitation processes within RegCM. J Geophys Res Atmos 105:29579-29594. https://doi.org/10.1029/2000jd900415

Phan VT, Ngo-Duc T, Ho TMH (2009) Seasonal and interannual variations of surface climate elements over Vietnam. Climate Res 40:49-60

Raghavan SV, Vu MT, Liong SY (2017) Ensemble climate projections of mean and extreme rainfall over Vietnam. Glob Planet Change 148:96-104. https://doi.org/10.1016/j.gloplacha.2016.12.003

Rahmat R, Archevarahuprok B, Kang CP, Soe W (2014) A regional climate modelling experiment for Southeast Asia. Centre for Climate Research Singapore, Meteorological Service Singapore Rep, p 127

Rasch PJ, Kristjánsson JE (1998) A comparison of the CCM3 model climate using diagnosed and predicted condensate parameterizations. J Climate 11:1587-1614. https://doi.org/10.1175/15200442(1998)011<1587:Acotcm>2.0.Co;2

Ratna SB, Ratnam JV, Behera SK, Tangang F, Yamagata T (2017) Validation of the WRF regional climate model over the subregions of Southeast Asia: climatology and interannual variability. Climate Res 71:263-280. https://doi.org/10.3354/cr01445

Rechid D, Hagemann S, Jacob D (2009) Sensitivity of climate models to seasonal variability of snow-free land surface albedo. Theor Appl Climatol 95:197-221. https://doi.org/10.1007/s0070 4-007-0371-8

Robertson A et al (2011) The Maritime Continent monsoon. In: The global monsoon system, pp 85-98. https://doi.org/10.1142/97898 14343411_0006

Roeckner E et al (1996) The atmospheric general circulation model ECHAM4: model description and simulation of present-day climate

Rotstayn LD (1997) A physically based scheme for the treatment of stratiform clouds and precipitation in large-scale models. I: description and evaluation of the microphysical processes. Q J R Meteorol Soc 123:1227-1282. https://doi.org/10.1002/qj.49712 354106

Salimun E, Tangang F, Juneng L, Behera SK, Yu W (2014) Differential impacts of conventional El Niño versus El Niño Modoki on Malaysian rainfall anomaly during winter monsoon. Int J Climatol 34:2763-2774. https://doi.org/10.1002/joc.3873

Samuelsson P, Gollvik S, Ullerstig A (2006) The land-surface scheme of the Rossby Centre regional atmospheric climate model (RCA3). SMHI (Meteorologi) https://www.smhi.se/sgn0106/if/ biblioteket/rapporter_pdf/meteorologi_122.pdf

Sasaki H, Kurihara K, Takayabu I, Uchiyama T (2008) Preliminary experiments of reproducing the present climate using the nonhydrostatic regional climate model. SOLA 4:25-28. https://doi. org/10.2151/sola.2008-007

Sass BH, Rontu L, Räisänen P (1994) HIRLAM-2 radiation scheme: documentation and tests. HIRLAM 3 Project, Swed. Meteorolog. and Hydrolog. Inst.

Savijärvi H (1990) Fast radiation parameterization schemes for mesoscale and short-range forecast models. J Appl Meteorol 1988-2005(29):437-447

Schmidt F (1977) Variable fine mesh in spectral global model. Beitr Phys Atmos 50:211-218

Schneider U, Becker A, Finger P, Meyer-Christoffer A, Ziese M, Rudolf BJT, Climatology A (2014) GPCC's new land surface precipitation climatology based on quality-controlled in situ data and its 
role in quantifying the global water cycle. Theor Appl Climatol 115:15-40. https://doi.org/10.1007/s00704-013-0860-x

Schwarzkopf MD, Fels SB (1991) The simplified exchange method revisited: an accurate, rapid method for computation of infrared cooling rates and fluxes. J Geophys Res Atmos 96:9075-9096. https://doi.org/10.1029/89jd01598

Sein DV et al (2015) Regionally coupled atmosphere-ocean-sea ice-marine biogeochemistry model ROM: 1 . Description and validation. J Adv Model Earth Systa 7:268-304. https://doi. org/10.1002/2014ms000357

Siew JH, Tangang FT, Juneng L (2014) Evaluation of CMIP5 coupled atmosphere-ocean general circulation models and projection of the Southeast Asian winter monsoon in the 21 st century. Int J Climatol 34:2872-2884. https://doi.org/10.1002/joc.3880

Smith RNB (1990) A scheme for predicting layer clouds and their water content in a general circulation model. Q J R Meteorol Soc 116:435-460

Supari TF, Salimun E, Aldrian E, Sopaheluwakan A, Juneng L (2018) ENSO modulation of seasonal rainfall and extremes in Indonesia. Climate Dyn 51:2559-2580. https://doi.org/10.1007/s00382-017-4028-8

Supari TF, Juneng L, Cruz F, Chung JX, Ngai ST, Salimun E, Mohd MSF, Santisirisomboon J, Singhruck P, Tan PV, Ngo-Duc T, Narisma G, Aldrian E, Gunawan D, Sopaheluwakan A (2020) Multi-model projections of precipitation extremes in Southeast Asia based on CORDEX-Southeast Asia simulations. Environ Res 184:109350. https://doi.org/10.1016/j.envres.2020.109350

Tang J, Niu X, Wang S, Gao H, Wang X, Wu J (2016) Statistical downscaling and dynamical downscaling of regional climate in China: present climate evaluations and future climate projections. J Geophys Res Atmos 121:2110-2129. https://doi.org/10.1002/2015jd023977

Tangang FT, Juneng L (2004) Mechanisms of Malaysian rainfall anomalies. J Climate 17:3616-3622. https://doi.org/10.1175/15200442(2004)017<3616:Momra>2.0.Co;2

Tangang FT et al (2008) On the roles of the northeast cold surge, the Borneo vortex, the Madden-Julian Oscillation, and the Indian Ocean Dipole during the extreme 2006/2007 flood in southern Peninsular Malaysia. Geophys Res Lett. https://doi. org/10.1029/2008g1033429

Tangang F, Latif M, Juneng L (2010) The roles of climate variability and climate change on smoke haze occurrences in southeast Asia Region. LSE Ideas, London

Tangang FT, Juneng L, Salimun E, Sei K, Le L, Halimatun M (2012) Climate change and variability over Malaysia: gaps in science and research information. Sains Malays 41:1355-1366

Tangang F, Farzanmanesh R, Mirzaei A, Supari SE, Jamaluddin AF, Juneng L (2017) Characteristics of precipitation extremes in Malaysia associated with El Niño and La Niña events. Int J Climatol 37:696-716. https://doi.org/10.1002/joc.5032

Tangang F et al (2018) Future changes in annual precipitation extremes over Southeast Asia under global warming of $2{ }^{\circ} \mathrm{C}$. APN Sci Bull. https://doi.org/10.30852/sb.2018.436

Tangang F et al (2019) Projected future changes in mean precipitation over Thailand based on multi-model regional climate simulations of CORDEX Southeast Asia. Int J Climatol. https://doi. org/10.1002/joc.6163

Taylor KE (2001) Summarizing multiple aspects of model performance in a single diagram. J Geophys Res Atmos 106:7183-7192. https ://doi.org/10.1029/2000jd900719

Tewari M, Chen F, Wang W, Dudhia J, LeMone MA, Mitchell K, Ek M, Gayno G, Wegiel J, Cuenca RH (2004) Implementation and verification of the unified NOAH land surface model in the WRF model. In: Paper presented at the 20th conference on weather analysis and forecasting/16th conference on numerical weather prediction, Seattle

Thatcher M, McGregor JL (2009) Using a scale-selective filter for dynamical downscaling with the conformal cubic atmospheric model. Mon Weather Rev 137:1742-1752. https://doi. org/10.1175/2008mwr2599.1

Tiedtke M (1989) A comprehensive mass flux scheme for cumulus parameterization in large-scale models. Mon Weather Rev 117:1779-1800. https://doi.org/10.1175/15200493(1989)117<1779:Acmfsf>2.0.Co;2

Trinh-Tuan L et al (2019) Application of quantile mapping bias correction for mid-future precipitation projections over Vietnam. SOLA 15:1-6. https://doi.org/10.2151/sola.2019-001

Valle D, Staudhammer C, Cropper W, Gardingen PR (2009) The importance of multimodel projections to assess uncertainty in projections from simulation models. Ecol Appl 19:1680-1692. https://doi.org/10.1890/08-1579.1

van der Linden R, Fink AH, Pinto JG, Phan-Van T, Kiladis GN (2016) Modulation of daily rainfall in southern Vietnam by the MaddenJulian Oscillation and convectively coupled equatorial waves. J Climate 29:5801-5820. https://doi.org/10.1175/jcli-d-15-0911.1

Vautard R, Gobiet A, Sobolowski S, Kjellström E, Stegehuis A, Watkiss P, Jacob D et al (2014) The European climate under a $2{ }^{\circ} \mathrm{C}$ global warming. Environ Res Lett. https://doi.org/10.1088/17489326/9/3/034006

Villafuerete MQ, Macadam I, Daron J, Katzfey J, Cinco TA, Ares ED, Jones RG (2019) Projected changes in rainfall and temperature over the Philippines from multiple dynamical downscaling models. Int J Climatol 40(3):1784-1804. https://doi.org/10.1002/joc.6301

Villafuerte MQ, Matsumoto J (2015) Significant influences of global mean temperature and ENSO on extreme rainfall in Southeast Asia. J Climate 28:1905-1919. https://doi.org/10.1175/jclid-14-00531.1

Waliser DE, Gautier C (1993) A satellite-derived climatology of the ITCZ. J Clim 6:2162-2174. https://doi.org/10.1175/15200442(1993)006<2162:Asdcot>2.0.Co;2

Wang B, Wu R, Li T (2003) Atmosphere-warm ocean interaction and its impacts on Asian-Australian Monsoon variation. J Climate 16:1195-1211. https://doi.org/10.1175/15200442(2003)16<1195:Aoiaii > 2.0.Co;2

Wilby RL, Wigley TML (1997) Downscaling general circulation model output: a review of methods and limitations. Prog Phys Geogr Earth Environ 21:530-548. https://doi.org/10.1177/0309133397 02100403

Xavier P et al (2020) Seasonal dependence of cold surges and their interaction with the Madden-Julian Oscillation over Southeast Asia. J Climate 33:2467-2482. https://doi.org/10.1175/ JCLI-D-19-0048.1

Yabu S, Murai S, Kitagawa H (2005) Clear sky radiation scheme. Sep Vol Annu Rep NPD 51:53-64 (in Japanese)

Yang B, Zhang Y, Qian Y, Huang A, Yan HJCD (2015) Calibration of a convective parameterization scheme in the WRF model and its impact on the simulation of East Asian summer monsoon precipitation. Climate Dyn 44:1661-1684. https://doi.org/10.1007/ s00382-014-2118-4

Yatagai A, Kamiguchi K, Arakawa O, Hamada A, Yasutomi N, Kitoh A (2012) APHRODITE: constructing a long-term daily gridded precipitation dataset for Asia based on a dense network of rain gauges. Bull Am Meteorol Soc 93:1401-1415. https://doi. org/10.1175/bams-d-11-00122.1

Zeng X, Zhao M, Dickinson RE (1998) Intercomparison of bulk aerodynamic algorithms for the computation of sea surface fluxes using TOGA COARE and TAO Data. J Climate 11:2628-2644. https://doi.org/10.1175/1520-0442(1998)011<2628:Iobaa f $>2.0 . \mathrm{Co} ; 2$

Publisher's Note Springer Nature remains neutral with regard to jurisdictional claims in published maps and institutional affiliations. 


\section{Affiliations}

\section{Fredolin Tangang ${ }^{1,2}(D)$ Jing Xiang Chung ${ }^{1,3}$. Liew Juneng ${ }^{1} \cdot$ Supari $^{1,4} \cdot$ Ester Salimun $^{1} \cdot$ Sheau Tieh Ngai ${ }^{1}$. Ahmad Fairudz Jamaluddin ${ }^{1,5}$. Mohd Syazwan Faisal Mohd ${ }^{6} \cdot$ Faye Cruz $^{7}$. Gemma Narisma ${ }^{7,8}$. Jerasorn Santisirisomboon ${ }^{2}$. Thanh Ngo-Duc ${ }^{9} \cdot$ Phan Van Tan $^{10}$. Patama Singhruck ${ }^{11}$. Dodo Gunawan ${ }^{4}$. Edvin Aldrian ${ }^{12} \cdot$ Ardhasena Sopaheluwakan $^{13} \cdot$ Nikulin Grigory $^{14} \cdot$ Armelle Reca C. Remedio $^{15}$. Dmitry V. Sein ${ }^{16,17}$. David Hein-Griggs ${ }^{18,19}$. John L. McGregor ${ }^{20}$ • Hongwei Yang ${ }^{21,22} \cdot$ Hidetaka Sasaki $^{23}$ • Pankaj Kumar ${ }^{24}$}

1 Department of Earth Sciences and Environment, Faculty of Science and Technology, Universiti Kebangsaan Malaysia, Bangi, Selangor, Malaysia

2 Ramkhamhaeng University Center of Regional Climate Change and Renewable Energy (RU-CORE), Bangkok, Thailand

3 Institut Oseanografi Dan Sekitaran (INOS), Universiti Malaysia Terengganu, Kuala Nerus, Terengganu, Malaysia

4 Center for Climate Change Information, Agency for Meteorology Climatology and Geophysics (BMKG), Jakarta, Indonesia

5 Malaysian Meteorological Department, Petaling Jaya, Selangor, Malaysia

$6 \quad$ National Hydraulic Research Institute of Malaysia (NAHRIM), Seri Kembangan, Selangor, Malaysia

7 Regional Climate Systems Laboratory, Manila Observatory, Quezon City, Philippines

8 Atmospheric Science Program, Physics Department, Ateneo de Manila University, Quezon City, Philippines

9 REMOSAT Laboratory, University of Science and Technology of Hanoi, Vietnam Academy of Science and Technology, Hanoi, Vietnam

10 Department of Meteorology and Climate Change, VNU University of Science, Hanoi, Vietnam

11 Department of Marine Science, Faculty of Science, Chulalongkorn University, Bangkok, Thailand
12 Agency for the Assessment and Application of Technology (BPPT), Jakarta, Indonesia

13 Center for Research and Development, Agency for Meteorology, Climatology and Geophysics (BMKG), Jakarta, Indonesia

14 Swedish Meteorological and Hydrological Institute, Norrköping, Sweden

15 Climate Service Center (GERICS), Hamburg, Germany

16 Alfred Wegener Institute (AWI), Bremerhaven, Germany

17 P. P. Shirshov Institute of Oceanology RAS, Moscow, Russia

18 Geography, College of Life and Environmental Sciences, University of Exeter, Exeter, UK

19 Met Office Hadley Centre, Exeter, UK

20 CSIRO, Canberra, Australia

21 APEC Climate Center (APCC), Busan, South Korea

22 School of Ecology and Environment, Inner Mongolia University, Hohhot, China

23 Meterological Research Institute, Tsukuba, Japan

24 Department of Earth and Environmental Sciences, Indian Institute of Science Education and Research Bhopal, Bhopal, India 